\title{
Deep-Pelagic (0-3000m) Fish Assemblage Structure Over the Mid- Atlantic Ridge in the Area of the Charlie-Gibbs Fracture Zone
}

April B. Cook

College of William and Mary - Virginia Institute of Marine Science

Follow this and additional works at: https://scholarworks.wm.edu/etd

Part of the Aquaculture and Fisheries Commons, Marine Biology Commons, and the Oceanography Commons

\section{Recommended Citation}

Cook, April B., "Deep-Pelagic (0-3000m) Fish Assemblage Structure Over the Mid-Atlantic Ridge in the Area of the Charlie-Gibbs Fracture Zone" (2011). Dissertations, Theses, and Masters Projects. Paper 1539617899.

https://dx.doi.org/doi:10.25773/v5-byt9-1638

This Thesis is brought to you for free and open access by the Theses, Dissertations, \& Master Projects at W\&M ScholarWorks. It has been accepted for inclusion in Dissertations, Theses, and Masters Projects by an authorized administrator of W\&M ScholarWorks. For more information, please contact scholarworks@wm.edu. 
Deep-pelagic (0-3000 m) Fish Assemblage Structure over the Mid-Atlantic Ridge in the area of the Charlie-Gibbs Fracture Zone

\author{
A Thesis \\ Presented to
}

The Faculty of the School of Marine Science

The College of William and Mary in Virginia

\author{
In Partial Fulfillment \\ of the Requirements for the Degree of \\ Master of Science
}

by

April B. Cook

2011 


\section{APPROVAL SHEET}

This thesis is submitted in partial fulfillment of the requirements for the degree of

Master of Science

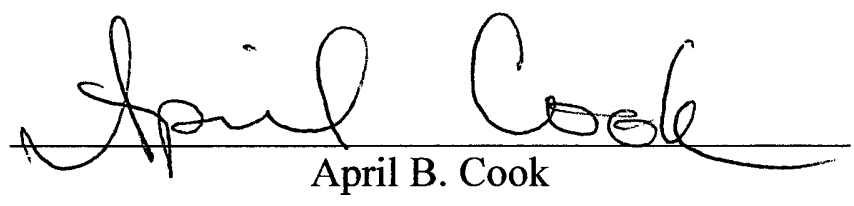

Approved, by the committee, November 2011

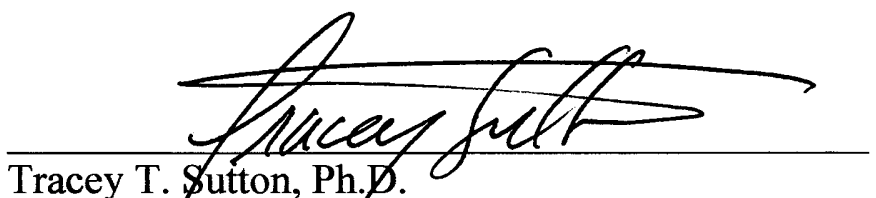

Committee Chairman/Advisor

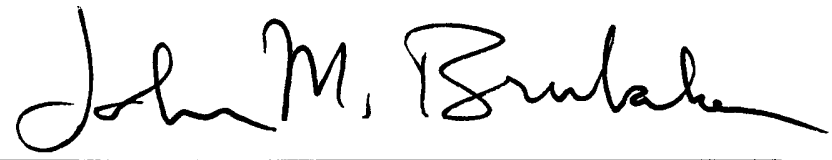

John M. Brubaker, Ph.D.
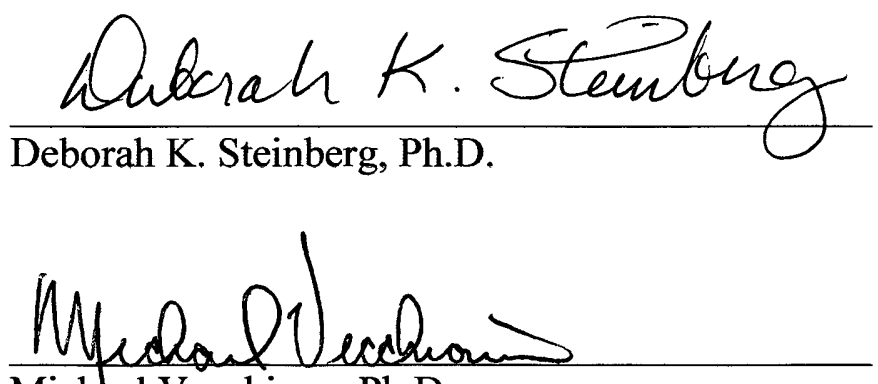

Michpel Vecchione, Ph.D. 


\section{DEDICATION}

This thesis is dedicated to the memory of Mary Zita Cook (1918-2011). Her love,

laughter, and joyous disposition inspired many of those around her including me. Should I become half the woman she was I will consider myself a success. 


\section{TABLE OF CONTENTS}

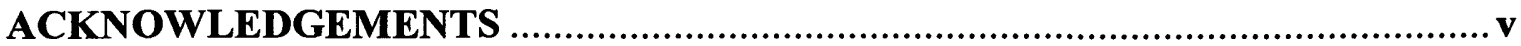

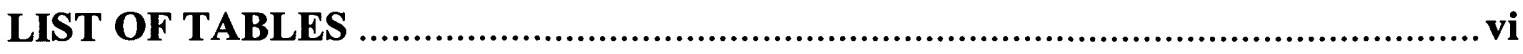

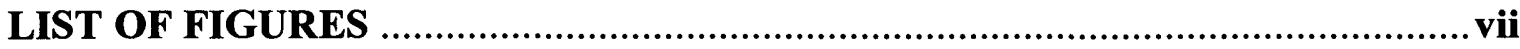

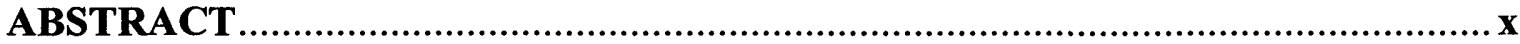

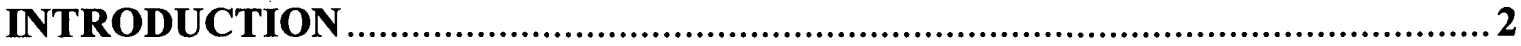

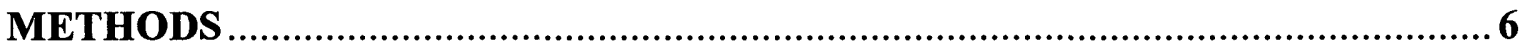

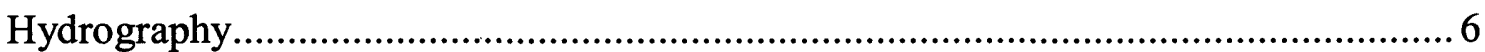

Trawl Sampling and Sample Processing............................................................. 7

Ichthyo faunal Composition and Diversity Measures..........................................9

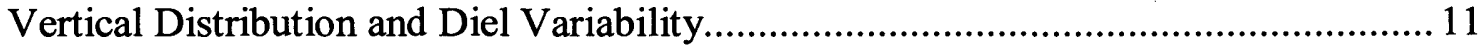

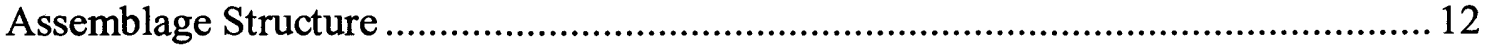

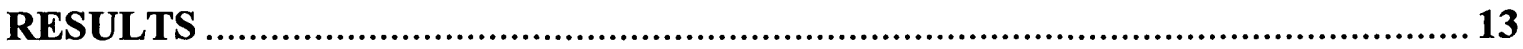

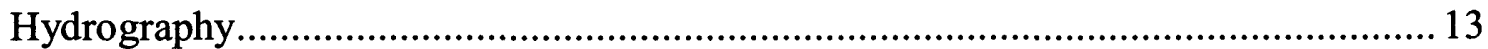

Ichthyofaunal Composition and Diversity Measures....................................... 14

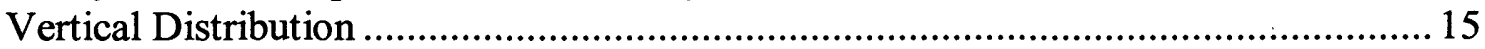

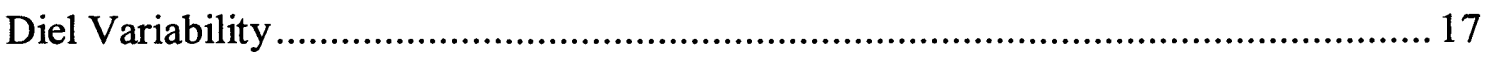

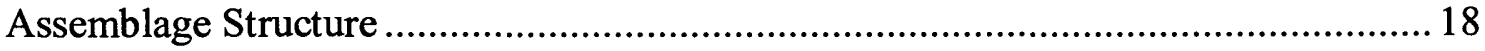

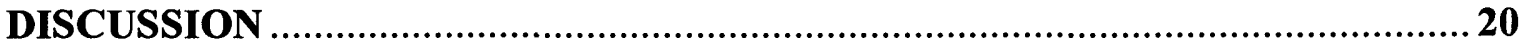

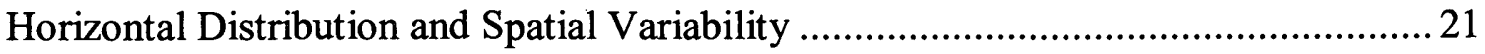

Diel Vertical Distribution....................................................................... 24

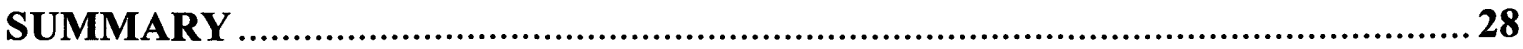

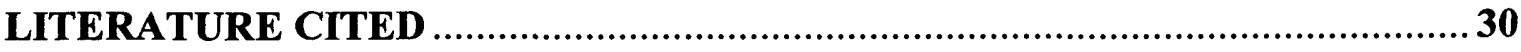

APPENDIX

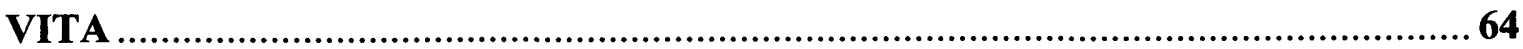




\section{ACKNOWLEDGEMENTS}

This work was made possible by the MAR-ECO program, led by Odd Aksel Bergstad and Tone Falkenhaug, to whom I am extremely grateful. NOAA's National Marine Fisheries Service provided both ship time and funding. I would like to thank the Captain and crew of the NOAA FSV Henry B. Bigelow for their support of the collecting activities as well as the science party for processing the samples at sea. I would also like to thank the Institute of Marine Research in Bergen, Norway, for providing the fishing gear and the expertise of Roar Skeide and Asbjorn Aasen.

I extend my deepest gratitude to my advisor, Tracey Sutton, who lured me away from sharks to the "dark side" of deep-sea fishes and opened my eyes to a cold, dark, mysterious world. His guidance, support, and witty sense of humor have been invaluable. I am grateful to Mike Vecchione for sharing his knowledge and experience of the deepsea and for showing me how to think critically. I am also grateful to Drs. John Brubaker and Deborah Steinberg for their advice and suggestions which expanded the breadth of this work. Many thanks go to John Galbraith for his friendship, guidance, and help on this project. Quantitative guidance and support from Dr. John Hoenig was greatly appreciated! Several people helped me learn how to use (and more importantly shortcuts for using) different programs to analyze data including Dr. Paul Somerfield, Pat Lynch, Catarina Wor, and Andre Buchheister.

Last but not least, I wish to thank my father, Tom Cook, whose interest in the natural world inspired my own from a very early age. Leading by example, he taught me how to fish, how to work hard, and much to his later dismay, how to be a successful, independent person. I thank my mother, Dana Cook, for her constant support and confidence in my abilities. She has made me the strong, competent woman I am today. My siblings, to whom I am truly grateful, have shared their experience, advice, and laughter which sustained me through many trying times. Thank you Terri, Chris, and Tony! Without the unconditional love and support of my family, the past two and a half years would not have been possible. 


\section{LIST OF TABLES}

Table

Page

1. Trawl data from the 2009 Henry B. Bigelow MAR-ECO expedition used for deeppelagic fish vertical distribution analysis and solar cycle analysis

2. Characterization of temperature profiles into hydrographic regimes ................. 40

3. Species richness $(S)$ and mean Shannon diversity indices .................................41

4. Integrated indices of diversity per sampling station.................................. 42 


\section{LIST OF FIGURES}

Figure

Page

1. Trawl sampling stations for Leg 1 of the $2004 \mathrm{R} / \mathrm{V}$ G.O. Sars MAR-ECO expedition

2. Trawl sampling stations of the $2009 \mathrm{R} / \mathrm{V}$ Henry B. Bigelow MAR-ECO expedition plotted on a weekly composite satellite image of sea-surface temperature $\left({ }^{\circ} \mathrm{C}\right)$.

3. Study area and trawl sampling stations of the $2009 \mathrm{R} / \mathrm{V}$ Henry B. Bigelow MARECO expedition.

4. Oblique sampling design for deep and shallow stations 46

5. Calculation of volume filtered by the macrozooplankton trawl (Wenneck et al. 2008)

6. In situ temperature profiles for stations in the study area 48

7. Diel vertical distribution of total deep-pelagic fish (a) abundance and (b) biomass over the Charlie-Gibbs Fracture Zone region of the Mid-Atlantic Ridge, standardized for effort, during both day and night. 50

8. Diel vertical distribution of total deep-pelagic fish (a) abundance and (b) biomass over the Charlie-Gibbs Fracture Zone region of the Mid-Atlantic Ridge, standardized for effort, during both day and night, with samples collected between 700-1000 m removed

9. Diel vertical distribution of numerically dominant deep-pelagic fish species over the Charlie-Gibbs Fracture Zone, standardized for effort, during both day and night: a) Cyclothone microdon; b) Benthosema glaciale; c) Maurolicus muelleri;

d) Protomyctophum arcticum. 
10. Diel vertical distribution of important fish biomass contributors over the CharlieGibbs Fracture Zone, standardized for effort, during both day and night: a)

Bathylagus euryops; b) Serrivomer beanii; c) Chauliodus sloani.

11. Dendrogram output from UPGMA hierarchical clustering of deep-pelagic fish samples collected in the vicinity of the Charlie-Gibbs Fracture Zone

12. Classification synopsis of deep-pelagic fish samples collected in the vicinity of the Charlie-Gibbs Fracture Zone, with cluster discrimination at 50\% similarity.. 54

13. Multi-dimensional scaling ordination plot of deep-pelagic fish samples collected in the vicinity of the Charlie-Gibbs Fracture Zone.

14. Shannon diversity indices for each sampling station.

15. Multi-dimensional scaling ordination plot of deep-pelagic fish samples delineated by depth zone and relative diversity

16. Boxplots of (a) abundance and (b) biomass between 1000-1900 m comparing day and night CPUE (catch standardized for volume of water filtered) 58 


\section{LIST OF APPENDICES}

Appendix

Page

I. Schematic of the macrozooplankton trawl (after Wenneck et al. 2008), with dimensions, and stretched mesh sizes.

II. Pelagic fishes collected from 0-2900 m during the 2009 Henry B. Bigelow expedition in the vicinity of the Charlie-Gibbs Fracture Zone of the northern MidAtlantic Ridge 60

III. Indices of diversity by sample for each station. $S=$ species richness, $H^{\prime}=$ Shannon diversity index. Depth zones and solar cycle codes as in Methods. 


\begin{abstract}
Only a miniscule fraction of the world's largest volume of living space, the ocean's mid-water biome, has ever been sampled. As part of the International Census of Marine Life field project Mid-Atlantic Ridge Ecosystems (MAR-ECO), a discrete-depth trawling survey was conducted in 2009 aboard the NOAA ship Henry B. Bigelow to examine the pelagic faunal assemblage structure and distribution over the Charlie-Gibbs Fracture Zone (CGFZ) of the northern Mid-Atlantic Ridge. This is the first MAR-ECO project aimed specifically at describing diel vertical migration as a distributional phenomenon. Discrete-depth sampling from 0-3000 m was conducted during both day and night in similar locations using a Norwegian "Krill" trawl with five codends that were opened and closed via a pre-programmed timer. Seventy-five species of fish were collected, with a maximum diversity and biomass observed between depths of 700-1900 $\mathrm{m}$. An incremental gradient in sea surface temperature and underlying watermasses, from northwest of the CGFZ zone to the southeast, was mirrored by a similar gradient in ichthyofaunal diversity. Using multivariate analyses, eight deep-pelagic fish assemblages were identified, with depth as the overwhelming discriminatory variable. Strong diel vertical migration (DVM) of the mesopelagic fauna was a prevalent feature of the study area, though the numerically dominant fish, Cyclothone microdon (Gonostomatidae), exhibited a broad (0-3000 m) vertical distribution and did not appear to migrate on a diel basis. In all, 3 patterns of vertical distribution were observed in the study area: a) DVM of mesopelagic, and possibly bathypelagic, taxa; b) broad vertical distribution spanning meso- and bathypelagic depths; and c) discrete vertical distribution patterns. Overall species composition and rank order of abundance of fish species agreed with two previous expeditions to the CGFZ (1982-83 and 2004), suggesting some stability in the ichthyo faunal composition of the study area, at least in the summer. Frequent captures of putative bathypelagic fishes, shrimps, and squid in the epipelagic zone (0-200 m) were confirmed. The results of this expedition reveal distributional patterns unlike those previously reported for open ocean ecosystems, with the implication of increased transfer efficiency of surface production to great depths in the mid-North Atlantic.
\end{abstract}


Deep-pelagic (0-3000 m) Fish Assemblage Structure over the Mid-Atlantic Ridge in the area of the Charlie-Gibbs Fracture Zone 


\section{INTRODUCTION}

The deep-pelagic realm of the world ocean, the largest biome on earth, is one of the least sampled and least understood (Webb et al. 2010). The boundaries within this midwater region (below $200 \mathrm{~m}$ to just above the seafloor) are not obvious, and it is mainly the physical properties of water itself (temperature, salinity, pressure, light penetration, currents) that provide any kind of structure (Angel 1997, Herring 2004, Sutton et al. 2008). Solar heat controls atmospheric and oceanic conditions, which stratifies the ocean such that environmental changes spatially occur far more rapidly in the vertical than the horizontal (Longhurst 1976, Herring 2004). Webb et al.'s (2010) study on the distribution of biodiversity underscores not only the lack of specimen records for the deep sea in general, but specifically for the midwater region.

It was once believed that the deep-sea was lifeless and was described as "azoic". We now know from numerous studies that the deep-sea supports many different life forms whose abundance and biomass decrease exponentially with depth in the open ocean (Vinogradov 1968, Angel and Baker 1982, Angel and Boxshall 1990, Robison 2004, Herring 2004, Sutton et al. 2010). These declines have been attributed to the diminishing food availability as distance increases from the productive surface waters of the epipelagic. The pelagic community is structured by both biotic and abiotic factors, namely the penetration of light which controls the production of phytoplankton and the flux of nutrients to depth via diel vertical migration (Cushing and Walsh 1976, Longhurst and Harrison 1988, Longhurst et al. 1990).

One of the most ubiquitous aquatic phenomena is diel vertical migration (DVM). This behavior has been observed and studied in both marine and deep freshwater systems 
since Cuvier's 1817 work on freshwater Cladocera (Cushing 1951). The controls and causes of DVMs have been the focus of numerous studies and include factors such as light (Backus and Clark 1965, Cohen and Forward 2009, Williamson et al. 2011), temperature/bioenergetics (Esterly 1912, Russell 1927, Busch et al. 2011), food availability (Marshall 1971, Huntley and Brooks, 1982, Pearre 2003), circadian endogenous rhythms (Harris 1963, Forward et al. 1996), and predator avoidance (Lampert 1989, Bollens et al. 1992, Herring 2004), to name a few. DVMs are not thought to occur in the bathypelagic zone (below $1000 \mathrm{~m}$ ) for several reasons: 1) organisms cannot perceive the diel changes in light intensity below this depth (Longhurst $1976)$; 2) the energy required for migration from these depths is greater than the energy gained from doing so, especially due to the swimming inefficiency of bathypelagic fishes, as most of their muscle mass has been replaced by energy-saving, neutrally-buoyant, watery tissue (Marshall 1971); and 3) much of what is known about DVM as a largescale phenomenon comes from acoustic surveys which cannot detect bathypelagic fishes that do not have swimbladders (Herring 2004); i.e., if bathypelagic DVM was occurring on the same scale as mesopelagic DVM, we may not detect it. Vinogradov $(1953,1968)$ proposed a "ladder of migrations" theory, which suggested an overlap between diel vertical migrators of the mesopelagic and the "lie-in-wait" predators of the bathypelagic, which then descend to even greater depths in ontogenetic migrations, supplying food down to depths of 4000-5000 m. Although Longhurst (1976) found Vinogradov's theory to be unsubstantiated, he stated that "If this model could be validated it would have important consequences in food-chain biology." The active transfer of organic material by vertically migrating organisms, however deep, is an important part of nutrient cycling 
in the ocean (Angel 1985, Longhurst and Harrison 1988, Dam et al. 1995, Zhang and Dam 1997, Angel and Pugh 2000, Steinberg et al. 2000, Ducklow et al. 2001, Robinson et al. 2010).

The gap in our knowledge of the deep-pelagic realm was one of the inspirations for the creation of a dedicated field project of the Census of Marine Life titled 'Patterns and Processes of the Ecosystems of the northern Mid-Atlantic Ridge' (MAR-ECO), which reached its operational stage in 2001 (Bergstad and Godø 2003). The primary aim of the project was to collect information regarding the faunal communities inhabiting the northern Mid-Atlantic Ridge (MAR), their distribution patterns, and their trophic interactions. The largest field campaign of MAR-ECO was the G.O. Sars expedition in the summer of 2004, which served as the project's main international and multidisciplinary effort (Bergstad et al. 2008). The goal of this campaign was to map the large-scale distribution of fauna along the northern MAR from Iceland to the Azores (Fig. 1). It was one of the first of its kind to employ multiple opening and closing codends mechanically adapted to a commercial style trawl, which allowed for discrete-depth sampling and the quantitative assessment of species composition, abundance, and biomass from the surface to abyssal depths (Wenneck et al. 2008). Findings from this expedition of a deep daytime biomass maximum and bathypelagic species collected in the epipelagic zone suggest that "the abundance and distribution of deep-pelagic fishes over the MAR differs from the 'typical' open ocean patterns" (Sutton et al. 2008). The authors attributed this deep biomass maximum to the presence of larger adult bathypelagic fishes believed to adopt a benthopelagic lifestyle, taking advantage of this fixed location for feeding and perhaps spawning, similar to findings near seamounts (Porteiro and Sutton 
2007). Due to the logistical constraints of this expedition, there was no diel station sampling replication; sampling was conducted at whatever time of day the ship arrived on station. Due to time of year (summer) and high latitude, sampling occurred mainly during daylight.

The coarse temporal and spatial resolution of the G.O. Sars expedition prompted a return expedition to a dynamic area of the ridge, the Charlie-Gibbs Fracture Zone (CGFZ), in the summer of 2009 aboard the NOAA ship R/V Henry B. Bigelow. The CGFZ has been referred to as the "gateway of the ridge" because there is a major flow of water between the western and eastern basins of the North Atlantic through deep transverse channels (Sy 1988, Rossby 1999, Bower et al. 2002). Read et al. (2010) found that while most of the water transported across the MAR north and south of the CGFZ occurred within the top $500 \mathrm{~m}$, transport through the fracture zone occurred between 500 $2500 \mathrm{~m}$ at a faster velocity. A near-surface frontal feature, known as the Subpolar Front, generally coincides with the CGFZ (Sy 1988, Sy et al. 1992), albeit with temporal variability (Bower and von Appen 2008), and marks the division between cold water to the north and warm water to the south (Fig. 2). Besides the MAR itself, oceanic fronts are believed to be the main potential biogeographic barriers in the open North Atlantic (Owen 1981, Angel 1993). The results of the GO Sars expedition revealed increased production and macrofaunal biomass near the Subpolar Front (e.g., Bergstad et al. 2008, Vecchione et al. 2010a), which was one of the research foci of this return voyage. The 2009 Bigelow expedition included day and night sampling for diel distribution comparisons as well as north/south sampling relative to the fracture zone to try to characterize assemblage structure variation across the Subpolar Front. 
The goal of this project is to gain a better understanding of the community structural dynamics of the pelagic fauna over a large, continuous topographic feature far removed from terrigenous inputs. To this end, the major questions addressed in this study are: 1) What is the structure and vertical distribution of deep-pelagic fish assemblages over the CGFZ region of the MAR and how do these patterns vary with respect to solar cycle? and 2) Is there fine-scale variability in the distribution of deeppelagic fish species within the Subpolar Frontal Zone with respect to the Charlie-Gibbs Fracture Zone?

\section{METHODS}

A multiple, discrete-depth trawl survey was conducted in the vicinity of the Charlie-Gibbs Fracture Zone (centered on $53^{\circ} \mathrm{N} 35^{\circ} \mathrm{W}$ ) during 20 June-6 July, 2009. Eleven fixed stations, divided into two transects, one northwest and one southeast of the CGFZ, were occupied for midwater trawling (Figs. 2, 3). Maximum bottom depths ranged from 1400-3000 m. Due to captures of putative bathypelagic fishes, shrimp, and squid in the top $200 \mathrm{~m}$, a shallow-water station with a maximum bottom depth of $753 \mathrm{~m}$ (located over a seamount) was sampled to rule out potential contamination effects of wash down from previous, deeper sampling into shallow-depth codends.

\section{Hydrography}

Daily and weekly-composite remote sensing satellite images of sea-surface temperature (SST) in the vicinity of the CGFZ were provided by the NERC Earth Observation Data Acquisition and Analysis Service (Fig. 2). In situ temperature data 
were recorded via a Seabird SBE 39 sensor mounted on the net during each deployment. Hydrographic regimes were characterized using temperature profiles as a proxy for water mass as salinity data were not recorded. Hydrographic conditions of the CGFZ region during the 2004 G.O. Sars expedition were described by Søiland et al. (2008). These descriptions guided the interpretation of temperature profile data collected in this study with respect to water mass.

\section{Trawl Sampling and sample processing}

Midwater trawling was conducted using a macrozooplankton (or "krill") trawl, designed at the Institute of Marine Research, Norway (Appendix I). This trawl had a 6×6$\mathrm{m}^{2}$ mouth opening and 3-mm diamond-shaped meshes from the front of the net to the codend. The trawl was equipped with Tiburon type- 8 midwater doors and a multisampler (remotely operated multiple codends). The multi-sampler had five $30-\mathrm{m}$ long codends, each equipped with a 7-L collection bucket to reduce damage to the samples. The codends were opened and closed by a pre-programmed timer based on depth from near bottom to the surface. This type of trawl does not have a rigid frame, so restrictor ropes were mounted in front of the trawl doors to avoid variation in door-spread, thus theoretically fixing the mouth area (Wenneck et al. 2008). The total trawl length from headrope to codend was $45 \mathrm{~m}$.

A continuous-oblique sampling strategy was employed, which resulted in five discrete-depth samples at deep stations whose maximum trawling depth was between 2700-2900 $\mathrm{m}$ and four discrete-depth samples at shallow stations whose maximum trawling depth was less than $1700 \mathrm{~m}$ (Table 1). For deep stations, the trawl was deployed 
to the maximum depth before the first codend was opened. All five codends were fished consecutively, opened/closed via timer from the maximum depth to the surface. At shallow stations the first codend was fished obliquely from the surface to the maximum depth (non-quantitative, or "meat" tow), the second was a horizontal tow at the maximum depth, and the third through fifth were timed to match the depths of codends $3-5$ at the deeper stations (Fig. 4). Codends 4 and 5 did not open at station 13 resulting in only two discrete-depth samples. Sampling was repeated in this location and recorded as station 14. This sampling scheme resulted in a total of 58 midwater samples, of which 50 were discrete-depth, quantitative samples.

The volume of water filtered by the macrozooplankton trawl was calculated using the equations presented in Wenneck et al. (2008). The trawl was assumed to be moving at a constant speed along an oblique trajectory (Fig. 5). The volume filtered $(V)$ by each codend was calculated as:

$$
V_{i}=T_{i} m
$$

where $T_{i}$ is the towing distance at depth interval $i$ and $m$ is the area of the mouth opening of the trawl, assumed to be $36 \mathrm{~m}^{2}$. The towing distance, $T_{i}$, was calculated as:

$$
\mathrm{T}_{i}=\sqrt{ }\left(D_{i}^{2}+H_{i}^{2}\right)
$$

where $D_{i}$ is the vertical extent of the depth interval $i$, and $H_{i}$ is the horizontal distance covered while trawling at depth interval $i$. Here we assumed that the net was always moving from depth toward the surface, that the net moved in a straight line, and that the wire length was a straight line and not a catenary. We also assumed that the mouth opening of the net remained constant and that water flow through the net was constant. 
As the trawl was brought on deck after sampling, the forenet was picked clean of all specimens entangled in the mesh in front of the multi-sampler to prevent contamination of future trawls. The specimens picked from the net were not included in any of the quantitative catch data presented here other than the total fish species list from the cruise. The catches were kept separate on deck by codend number. The codend samples were processed sequentially, from the deepest depth stratum sampled to the shallowest. While processing each sample, all other samples were stored in a cold room to prevent degradation. The total wet weight of each sample was recorded via a motioncompensating scale. The catch was then rough-sorted to major taxonomic group (fishes, crustaceans, cephalopods, gelatinous megaplankton). Fishes then were sorted by taxon and further identified to species. All fishes were counted and weighed by species onboard. Obtaining wet weights while at sea precluded the need for 'back-calculating' biomass measures by volume displacement or length-weight regressions post cruise. Samples were then either frozen in seawater or preserved in $10 \%$ formalin:seawater $(\mathrm{v} / \mathrm{v})$ and are currently curated at the Virginia Institute of Marine Science in Gloucester Point, Virginia, USA.

\section{Ichthyofaunal composition and diversity measures}

Data matrices consisted of abundance and biomass (per $10^{4} \mathrm{~m}^{3}$ water filtered) of fish species per trawl sample. Prior to statistical analyses the data matrices were fourthroot transformed to down-weight the numerically dominant species (namely, Cyclothone microdon and Benthosema glaciale). This strong transformation was chosen based on the 'range of values' criterion (Sutton et al. 2008) because other statistical methods, such as 
dispersion-based weighting, require sample replication. This transformation was justified due to the range of non-zero abundances which spanned five orders of magnitude.

Diversity of samples was expressed as species richness (S) and as the Shannon diversity index $(H)$. Species richness equaled the total number of species present in a sample. The Shannon diversity index was calculated as:

$$
H^{\prime}=-\sum_{i=1}^{S} p_{i} \log _{2} p_{i}
$$

where $p_{i}=\frac{n_{i}}{N}, n_{i}=$ the number of individuals in the $i$ th species, $N=$ the total number of species in all samples, and $S=$ the number of species in a sample. Hypothesis tests were used to compare the Shannon diversity indices of samples and/or stations to detect changes in ichthyofaunal biodiversity as a function of: 1) depth, 2) solar cycle, 3) location, or 4) hydrography. Depth was investigated using a one-way analysis of variance (ANOVA) comparing the diversity indices of all 50 samples. The effect of solar cycle on sample diversity was investigated using a one-way ANOVA on a subset of samples ranging from $0-700 \mathrm{~m}$, collected during day and night only (but not including dusk or dawn samples - see definitions below). The mean diversity indices for the entire water column (pooled abundance) at each station were compared using Welch's $t$ test, accounting for unequal variance, as a function of location in relation to the fracture zone (i.e., NW, SE) and as a function of "hydrographic region" (i.e., SAIW, Frontal) defined in Søiland et al. (2008). Stations 9-15, northwest of the fracture zone, were grouped together as "NW" (Fig. 3). Stations 16-21, southeast of the fracture zone, were grouped together as "SE" (Fig. 3). Fixed geographic locations were investigated due to the interjection of the ridge crests to $1000 \mathrm{~m}$ depths which could affect pelagic distributions. 


\section{Vertical distribution and diel variability}

Discrete-depth trawl data were assigned to a depth zone for vertical distribution analysis: Zone $1(0-200 \mathrm{~m})$, Zone $2(201-700 \mathrm{~m})$, Zone $3(701-1900 \mathrm{~m})$, and Zone 4 (1901-2900 m). Samples were only assigned to a depth zone when at least $90 \%$ of the sample was wholly contained within that zone's depth range. Samples that extended into more than one pre-defined depth zone were not included in the analysis. Ichthyofaunal composition of each depth zone was collated. Major vertical distribution patterns were elucidated using data for those species which made up at least $1 \%$ of the total catch.

Temporal variability of vertical distribution was examined using solar cycle data following the methods of Sutton et al. (2008). Each sample was classified as either day (D), dusk (DN), night (N), or dawn (ND) using sunrise and sunset times calculated for each sampling location and time. Dawn and dusk samples were defined as those that were collected above $800 \mathrm{~m}$ depth at least one hour outside of sunrise and sunset. All samples below $800 \mathrm{~m}$ were considered either day or night only, assuming that solar light does not penetrate below this depth in the North Atlantic (Clarke and Denton 1962). Using the pre-defined depth zone scheme, standardized abundance and biomass throughout the water column for all species were plotted to illustrate day vs. night vertical distributions. One particular fish specimen (Trachipterus arcticus) was removed from this analysis because its weight $(7 \mathrm{~kg})$ was several orders of magnitude larger than the average specimen. Individual plots were created for the numerically dominant species (the smallest number of species whose collective abundance represented at least $95 \%$ of the total abundance), and/or whose biomass contributed at least $5 \%$ to the total biomass. These plots will be used to illustrate the major patterns of diel variability. 


\section{Assemblage Structure}

Two multivariate techniques were used to discriminate natural fish assemblages without prior assumptions employing the PRIMER v.6 statistical software package (Clarke and Gorley 2006): non-metric multi-dimensional scaling (MDS, Kruskal and Wish 1978) and hierarchical unweighted pair-group cluster analysis using arithmetic averages (UPGMA, Romesburg 1990). Both analyses were based on a Bray-Curtis similarity matrix created from the $\sqrt[b]{ }$ - transformed data matrix. The Bray-Curtis similarity coefficient method was chosen because joint absences have no effect on the results (Bray and Curtis 1957, Faith et al. 1987). This is important because there are many possible reasons for the absence of a particular species, such as depth, water mass, etc. Assuming that two samples are similar based on the absence of a particular species could be misleading.

Similarity profile permutation tests (SIMPROF; 1000 iterations, $P<0.05$ ) were run to test the null hypothesis that samples did not differ from each other in multivariate structure. The similarity level at which the departure statistic, $\pi$, exceeded the $5 \%$ probability criterion was used to define assemblage groups via cluster analysis. The resulting assemblage structure was qualitatively compared with the findings of Sutton et al. (2008) near the CGFZ.

A series of similarity permutation tests (ANOSIM; 999 iterations) were run to test the null hypothesis that there were no differences between groups of samples as a function of four a priori factors. The four factors were: 1) solar cycle, 2) depth zone, 3) geographic region, i.e., station location relative to CGFZ, and 4) hydrographic regime as described using temperature profiles. If the null hypothesis was rejected, meaning the 
results of the global test were significant $(P<0.05)$, pairwise tests were conducted to identify where major differences occurred relative to each factor. If the null hypothesis could not be rejected, no further testing was conducted.

\section{RESULTS}

\section{Hydrography}

The remote-sensed SST image from late June 2009 (Fig. 2) showed cold surface water to the northwest which transitioned to warmer surface water in the southeast corner of the study area. Sea-surface temperatures ranged from $8-12{ }^{\circ} \mathrm{C}$. Mesoscale eddies were apparent in the transition zone between NW and SE stations (Fig. 2). The steepest temperature gradient within this zone, coinciding with the Subpolar Frontal Zone, was located around $52^{\circ} \mathrm{N}$ and $30^{\circ}-35^{\circ} \mathrm{W}$ (Søiland et al. 2008). Temperature profiles for each station are presented in Figure 6. These profiles suggest the presence of three primary and one secondary upper-water-column $(<1000 \mathrm{~m})$ hydrographic regimes in the study area, characterized by water temperatures at 0,200 , and $700 \mathrm{~m}$ depth (Table 2, Fig. 6). Regime 1 (stations $9,11,12,13 / 14,15$ ) was characterized by a surface temperature $\leq 9^{\circ} \mathrm{C}$, a 200 $\mathrm{m}$ temperature of $5-6^{\circ} \mathrm{C}$, and a $700-\mathrm{m}$ temperature $\leq 4^{\circ} \mathrm{C}$. Regime $1 \mathrm{~b}$ (stations 16,18 ) exhibited slight warming throughout the water column and was characterized by a surface temperature of $10-11^{\circ} \mathrm{C}$, a $200-\mathrm{m}$ temperature around $6^{\circ} \mathrm{C}$, and a $700-\mathrm{m}$ temperature slightly greater than $4^{\circ} \mathrm{C}$. Regime 2 (stations $17,19,20$ ) showed considerable warming throughout the water column and was characterized by a surface temperature of $11-12^{\circ} \mathrm{C}$, a $200-\mathrm{m}$ temperature of $7^{\circ} \mathrm{C}$, and a $700-\mathrm{m}$ temperature of $4.5^{\circ} \mathrm{C}$. Regime 3 (station 21) 
was characterized by a surface temperature $>12^{\circ} \mathrm{C}$, a $200-\mathrm{m}$ temperature $>8^{\circ} \mathrm{C}$, and a 700 -m temperature $>4.5^{\circ} \mathrm{C}$.

Søiland et al. (2008) identified two "hydrographic regions" in the study area based on the predominant water mass in the upper $500 \mathrm{~m}$ of the water column from the 2004 G.O. Sars expedition (Table 2). The temperature profiles collected during that expedition were qualitatively compared with those of the current study, assuming salinity to be a much lesser component of variation. Comparisons revealed that stations belonging to regimes 1 and $1 \mathrm{~b}$ above were dominated by Sub-Arctic Intermediate Water (SAIW) and were identified as the SAIW Region. The stations belonging to regimes 2 and 3 were a mixture of SAIW and North Atlantic Central Water (NACW) which were identified as the Frontal Region.

\section{Ichthyofaunal composition and diversity}

In total, 18,250 fish specimens were collected, representing at least 75 fish species (61 genera) from 29 families and 14 orders. A complete species list by station is presented in Appendix II, which includes the raw abundances/biomasses (not normalized for effort), $\%$ of total catch, and the frequency of occurrence for each species (note: some taxa are currently undergoing taxonomic revision and/or require further examination). The dominant species collected in terms of both abundance and biomass was Cyclothone microdon (Gonostomatidae).

Species richness (S) and Shannon diversity indices $\left(\mathrm{H}^{\prime}\right)$ are presented for each sample in Appendix III. The station number, depth zone, and solar cycle for each sample are included to assess diversity differences among samples as a function of depth and 
time of day. Species richness, total abundance, and mean diversity $\left(H^{\prime}=2.42\right)$ were all highest between depths of 700-1900 m (Table 3). This was only slightly higher than the mean diversity between $200-700 \mathrm{~m}\left(\mathrm{H}^{\prime}=2.22\right)$. The lowest mean diversity $\left(\mathrm{H}^{\prime}=1.38\right)$ was found below $1900 \mathrm{~m}$ (Zone 4). This was only slightly lower than the mean diversity of the epipelagic region (Zone $\left.1 ; H^{\prime}=1.78\right)$.

ANOVA results suggested that assemblage diversity varied significantly with depth $(P<<0.01, \mathrm{~F}=12)$. The time of day (solar cycle) was not a significant factor for the 0-700 m samples $(P=0.86, \mathrm{~F}=0.03)$. When comparing the whole water column

diversity indices for each station (Table 4), geographic location in relation to the CGFZ itself was not a significant factor $(P=0.12, F=2.7)$, but Søiland et al.'s (2008) "hydrographic region" was significant $(P<0.05, \mathrm{~F}=5.8)$.

\section{Vertical distribution}

The vertical distribution analyses of all samples combined revealed clear differences in faunal composition between depth zones sampled. A total of 18 species was collected between $0-200 \mathrm{~m}$. The most abundant fish families in this zone were Myctophidae, comprising more than half of the total abundance (58\%), followed by Gonostomatidae (36\%), Stomiidae and Sternoptychidae (both $2 \%$ and only collected at night), and Bathylagidae (1\%). Of the Myctophidae, Benthosema glaciale was dominant (half of total fish abundance in this stratum), followed by Protomyctophum arcticum (8\% of total). Cyclothone microdon was the dominant gonostomatid (30\% of total), followed by $C$. braueri $(3 \%)$. The remaining 14 species all contributed less than $2 \%$ to total fish numbers within this depth zone. 
Thirty-three species were collected between $200-700 \mathrm{~m}$. The family Gonostomatidae contributed $62 \%$ of total fish abundance in this stratum (Cyclothone microdon and C. braueri, 56\% and 5\% of totals, respectively). Myctophidae comprised $26 \%$ of the catch in this depth zone, with Benthosema glaciale and Protomyctophum arcticum again most abundant species (18\% and $8 \%$ of totals, respectively). The Sternoptychidae ( $8 \%$ of totals) was represented primarily by the pearlside, Maurolicus muelleri $(96.5 \%$ of the family total). Stomiidae ( $3 \mathrm{spp}$.$) and Melamphaidae ( 5 \mathrm{spp}$.$) both$ contributed about $1 \%$ to total fish numbers within this depth zone.

The highest species richness in this study was observed between 700-1900 m, with 56 species collected. The Gonostomatidae were most abundant (90\%), followed by Myctophidae (5\%), Melamphaidae (2\%), Bathylagidae and Sternoptychidae (both 1\%). Though species number was higher compared to shallower strata, numerical dominance was more prevalent in this stratum; $89 \%$ of total fish abundance was from one species, Cyclothone microdon, and only three other species comprised at least $1.5 \%$ (Protomyctophum arcticum [2\%], Benthosema glaciale [2\%], and Bathylagus euryops [1.5\%]). The remaining 52 species combined contributed $\sim 5 \%$ to total fish numbers within this depth zone.

The deepest sampling zone, $1900-2900 \mathrm{~m}$, was the least speciose (14 spp.) and was numerically dominated by the Gonostomatidae; Cyclothone microdon comprised $96 \%$ of the total abundance. The Melamphaidae (1.6\%; primarily Scopeloberyx robustus) and Myctophidae (1.2\%) were the only other fish families contributing at least $1 \%$ to the total number of fishes collected within this zone. 


\section{Diel variability}

The pooled vertical distribution of fish abundance, standardized for effort, during both day and night sampling, is presented in Figure 7a. The greatest abundance of fishes during the day occurred between $200-700 \mathrm{~m}$, but at night this shifted to the top $200 \mathrm{~m}$. The pooled vertical distribution of fish biomass during both day and night is shown in Figure $7 \mathrm{~b}$. The greatest biomass of fishes during the day occurred between $700-1900 \mathrm{~m}$ but shifted up at night to the top $200 \mathrm{~m}$. The depth range of this daytime biomass maximum encompasses both the meso- and bathypelagic zones, so in order to investigate this further, the samples collected between 700-1000 m (bottom of mesopelagic zone) were removed. The resulting plots are presented in Figure 8a-b. The modified abundance plot (Fig. 8a) revealed the same shift of abundance from the mesopelagic during the day to the epipelagic at night, with similar daytime abundance values in the mesopelagic. The nighttime abundance values in this zone were lower after removal of the $700-1000-\mathrm{m}$ samples, suggesting these samples were of higher abundance than the 1000-1900 m samples. The biomass plot provided additional evidence that the diel shift from $700-1900$ $\mathrm{m}$ to $0-700 \mathrm{~m}$ at night included the bathypelagic $(>1000 \mathrm{~m})$ fauna; daytime biomass between 700-1900 m was consistent with biomass between 1000-1900 m (Figs. $7 \mathrm{~b}$ and 8b), while the nighttime biomass between 1000-1900 m was lower than that of 700-1900 m.

Vertical distribution plots for dominant species are presented in Figures 9-10. Cyclothone microdon contributed $78 \%$ of the total abundance of fishes collected during this expedition. C. microdon had a maximum abundance between $700-1900 \mathrm{~m}$ and little diel variation (Fig. 9a). The most abundant myctophid, Benthosema glaciale, was 
collected primarily in the top $200 \mathrm{~m}$ at night with evidence of strong DVM (Fig. 9b). The vertical distribution of Maurolicus muelleri was concentrated between 0-700 m day and night, with some evidence of DVM from the deepest individuals (700-1900 m) (Fig. 9c). Another myctophid, Protomyctophum arcticum, was also found mainly in the epipelagic at night and showed evidence of DVM (Fig. 9d). Bathylagus euryops, a high biomass species ( $16 \%$ of total) was distributed broadly throughout the water column, but was most abundant between 700-1900 m both day and night (Fig. 10a) and showed no evidence of DVM. The distribution of Serrivomer beanii, which constituted $8 \%$ of the total biomass, was indicative of a very deep DVM, with daytime abundances evenly spread between 200-2900 $\mathrm{m}$ and nighttime abundances primarily between 0-700 $\mathrm{m}$ (Fig. 10b). The numerically significant species Chauliodus sloani was collected in highest abundance between 200-700 $\mathrm{m}$ day and night (Fig. 10c), with no apparent evidence of DVM for this species.

\section{Assemblage structure}

Similarity profile permutation tests (SIMPROF) of cluster analysis revealed eight major assemblages at a similarity level of $50 \%(\pi=1.74, P=0.025)$. Evidence of substructure at higher similarity values could not be found (at $53 \% \pi=1.58, P=0.07$ ). The dendrogram output of cluster analysis is presented in Figure 11 and the characteristics of each of the eight assemblages in Figure 12. Group H (Sample 1902) was an outlier with a unique species composition (including two species found solely in this sample) and relative abundance. The removal of this sample had no affect on the results, so this sample was retained for all further analyses. Depth, the primary factor 
differentiating assemblages, was evident in the three largest assemblages (Groups A, B, and F). Group A contained 12 samples primarily collected from the deepest zone (1900$2900 \mathrm{~m}$ ), with few collected shallower than $1900 \mathrm{~m}$. The 10 samples in Group B were, with the exception of one, collected between 700-1900 m. The largest assemblage, Group F, was comprised of samples ranging in depth from 0-1900 m which encompassed diel vertical migrators. Groups $\mathrm{C}$ and $\mathrm{E}$ each contained only two samples which were both collected from the same depth range of $700-1900 \mathrm{~m}$ and $0-200 \mathrm{~m}$, respectively. The remaining Groups D and G were single sample outliers collected from 700-1900 m and 200-700 m, respectively.

The results of the ANOSIM tests indicated that depth was the primary factor differentiating each assemblage $(\mathrm{R}=0.412, P<0.01)$. Pairwise comparisons indicated that all depth zones were significantly different $(\mathrm{R}=0.415-0.813, P<0.01)$ with the exception of Zones 1 and $2(\mathrm{R}=0.132, P=0.076)$. Geographic region (NW vs. SE of fracture) as a factor was significant $(\mathrm{R}=0.073, P=0.022)$, as was hydrographic regime (differentiated from temperature profiles; $\mathrm{R}=0.115, P=0.036$ ), but both at lower levels. Pairwise comparisons indicated that only Hydrographic Regimes 1 and 3 were significantly different $(\mathrm{R}=0.11, P=0.043)$. The null hypothesis could not be rejected for solar cycle as a factor $(\mathrm{R}=-0.032, P=71.0)$, therefore, no further analysis was conducted.

The ordination (MDS) result is presented graphically in Figure 13. There was a clear pattern with depth as the samples followed a parabolic form in which depth separated the three major clusters. The eight assemblages discriminated by cluster analysis at a $50 \%$ similarity level are labeled on the plot, showing concordance between 
classification and ordination techniques in discriminating deep-pelagic assemblages over the CGFZ. This finding also emphasizes the relative importance of depth as an explanatory factor - no such concordance was observed with respect to any other factor (e.g., location, solar cycle, water mass).

\section{DISCUSSION}

The mid-ocean ridge system of the North Atlantic is a vast structure that constitutes as much as $46 \%$ of the deep-benthic $(800-3500 \mathrm{~m})$ habitat (Priede et al. submitted). Still the ecology and fauna of this feature is poorly understood (Bergstad et al. 2008). The MAR itself acts as a divider between the eastern and western North Atlantic, with deep water exchange occurring mainly through channels at fracture zones. In the North Atlantic, the exchange of deep water (west to east) and a meeting of two major water masses (SAIW and NACW) all occur in the area of the CGFZ. In addition to the abrupt topography and dynamic hydrography, the 2004 G.O. Sars expedition provided ample evidence that the region surrounding the CGFZ represents a 'biological hotspot' across multiple trophic levels (Vecchione et al. 2010a). Gaard et al. (2008) found that phytoplankton biomass was highest in the Frontal Region (as previously defined), which agreed with earlier findings of Clark et al. (2001) and Gallienne et al. (2001). This was attributed to shallow hydrographic stratification leading to increased nutrient availability within the euphotic zone. Gislason et al. (2008) noted higher values of chlorophyll $a$ and higher egg production rates of the copepod Calanus finmarchicus near the CGFZ. Higher relative concentrations of gelatinous zooplankton (Stemmann et al. 2008, Youngbluth et al. 2008) and chaetognaths (Pierrot-Bults 2008) have been observed 
in the Frontal Region. Opdal et al. (2008) observed maximum 38-kHz acoustic backscatter (a proxy for micronekton biomass) in the region of the CGFZ, relative to regions north and south. Fossen et al. (2008) observed higher catch rates of demersal fishes from a bottom longline over shallow sections of the CGFZ. Sperm and sei whales were also found to aggregate near frontal features in the CGFZ region (Skov et al. 2008). Opdal et al. (2008) suggested that the concentration of biota in this region was due to an interaction between topographic features, circulation, and primary productivity. These findings indicate that the region surrounding the CGFZ is an area of enhanced biotic activity and interaction. In this study, I address two major topics in this oceanic region:

1. The effect of the Subpolar Front on fine-scale variability in the distribution of deep-pelagic fishes in the mid-North Atlantic;

2. The diel vertical distribution of deep-pelagic fishes, which has not been previously addressed in studies of the MAR.

\section{Horizontal Distribution and Spatial Variability}

The overall faunal composition reported in this study generally fit the patterns reported for the 2004 G.O. Sars expedition, which revealed two major pelagic fish assemblages in the area of the CGFZ discriminated at a depth of $750 \mathrm{~m}$ (Sutton et al. 2008). Although the current study provided a higher resolution and resulted in a greater number of assemblages, the general pattern is consistent with previous studies. The primary exception was the absence in this study of the snake pipefish, Entelurus aequoreus, which was the fourth-most abundant species of 0-750 m pelagic fish assemblage characterized by Sutton et al. (2008) for the CGFZ area. The remaining 
dominant species for both abundance and biomass were similar to those collected during this study within the same depth range. The rank order of abundance and biomass differed slightly but the top five species were consistent.

The deeper fish assemblage found by Sutton et al. (2008) between 750-2300 m (their Group III) extended almost the entire length of the northern MAR. This assemblage was dominated both in abundance and biomass by Cyclothone microdon and Bathylagus euryops followed closely by Scopelogadus beanii. In comparison, the top five species in terms of abundance in this study between $700-2900 \mathrm{~m}$ included two myctophids (Benthosema glaciale and Protomyctophum arcticum) and a sternoptychid (Maurolicus muelleri), in addition to $C$. microdon and B. euryops. The biomass-dominant species reported in this study were very similar to those found in 2004. The difference in the rank order of species abundance may have been a result of differing depth strata or, more likely, the scale of the expedition. Although the two studies were conducted in different years on different scales, the consistency suggests that the summertime deep-pelagic fish assemblage in the area of the CGFZ is fairly stable.

ANOVA results showed a relationship between diversity and Søiland et al.'s (2008) "hydrographic region" (SAIW or Frontal), but not geographic region (NW or SE of fracture) in the CGFZ study area. The diversity indices calculated for each station showed an incremental increase from the NW subarea to the SE subarea (Fig. 14) due to the increase in additional species which followed the same gradient as temperature. This finding indicates that this study area was encompassed by the Subpolar Frontal region, evidenced by the sea surface temperature gradient from NW to SE and the prevalence of mesoscale eddies within the study area (Fig. 2). The intensity of the mesoscale eddies in 
the SE subarea may confound any attempt to significantly differentiate assemblages at a specific geographic location, as a given station will experience several water masses over very short timescales. The water mass being sampled at a given location at one time may be replaced by another water mass at another time. This eddy field could be the mechanism that enhances diversity. The majority of studies from the 2004 G.O. Sars expedition found the sharpest faunal breaks to be well south of the CGFZ in the Faraday Seamount Zone (Hosia et al. 2008, Sutton et al. 2008, Vecchione et al. 2010b).

Deep-pelagic fish diversity was significantly related to depth, with the highest diversity value found between 700-1900 m. It should be acknowledged that the vertical extent of the depth zone bins were unequal. Depth zone 3 (700-1900 m) was the largest which spanned $1200 \mathrm{~m}$ and sampled both meso- and bathypelagic fauna. This could contribute to the higher mean diversity index in this zone, though a similar depth bin size in the zone below (1900-2900) yielded a minimum diversity index. It is more likely that the presence of both meso- and bathypelagic fishes in the 700-1900 m depth zone was most responsible for the observed diversity maximum. Depth was the primary factor discriminating ichthyofaunal assemblages as well. Ordination results (Fig. 13) show three major assemblages which can clearly be related to depth. However, if depth is the prevailing factor, then why were the MDS groupings not linear? One might expect to see more of a linear gradient with depth as has been shown for much of this data set $(e . g$. temperature, water mass, diversity). It should be noted that an ordination is merely a graphical representation of the underlying Bray-Curtis similarity matrix, which is based on the relative abundance and species composition as opposed to absolute. So the question then becomes 'What makes the lower bathypelagic and epi-/upper mesopelagic 
samples more similar to each other than one would expect based solely upon depth?' It is likely that the higher species richness and diversity between 700-1900 $\mathrm{m}$ (Table 3) separates the deep meso/bathypelagic samples, as illustrated in Figure 15 ("left-hand shift"), instead of the linear gradient of samples based solely on temperature as a univariate factor. Depth was a much more important factor $(R=0.412)$ than geography $(\mathrm{R}=0.073)$ or hydrography $(\mathrm{R}=0.115)$, so the remainder of this discussion will focus on the vertical structure of the fish assemblages over the CGFZ.

\section{Diel vertical distribution}

The total deep-pelagic fish assemblage within the CGFZ study area (Fig. 7a) exhibited a maximum in abundance within the mesopelagic zone (200-700 m) during the day. This abundance maximum then shifted to the epipelagic zone $(0-200 \mathrm{~m})$ at night. These results fit the expectation of diel vertical migration (DVM) in the mesopelagic zone of the North Atlantic (Backus et al. 1977, Angel 1989, Hays 1996), but are confirmed here for the first time in the CGFZ. Looking at species-specific distributions, we see the "classic" DVM pattern for Benthosema glaciale (Fig. 9b), with a maximum abundance between 200-700 m during the day and between 0-200 $\mathrm{m}$ at night. This agrees with distributions previously described for the North Atlantic (Halliday 1970, Craddock et al. 2002, Angel 1993). The vertical distribution and diel variability of Maurolicus muelleri (Fig. 9c) also fits the reported patterns for the North Atlantic (Bergstad 1990, Quéro et al. 1990b). Protomyctophum arcticum, the second-most abundant myctophid, exhibited a meso- to epipelagic DVM over the CGFZ (Fig. 9d) that generally agrees with published reports (Hulley 1984; Mauchline 1988). These zooplanktivorous, vertically 
migrating fishes were likely undertaking DVM to utilize an abundant food source (copepods) in the surface waters. Gaard et al. (2008) found that 53\% of copepod abundance was found above $100 \mathrm{~m}$ and $75 \%$ above $500 \mathrm{~m}$ over the northern MAR. These authors sampled during the same time of year in 2004 and found this region to be in a post-phytoplankton bloom situation, which agrees with earlier findings that the spring bloom begins in April, peaks in May, and declines in June (Gislason 2003). It is important to note that all of the vertical distribution patterns presented here are those of summertime, specifically late June.

The modified plot of diel vertical distribution (Fig. 8a) clearly shows a reduction in abundance between 1000-1900 m from day to night and an increase in abundance between $700-1000 \mathrm{~m}$. This signal is in part due to the deep (bathy- to mesopelagic) vertical migration of Serrivomer beanii (Fig. 10b), whose overall vertical distribution has been reported for the North Atlantic as a whole (Bauchot, M.-L. 1986), but whose diel variation is reported here for the first time. The modified vertical distribution plot (Fig. 8b) revealed a daytime biomass maximum in the bathypelagic zone (1000-1900 m), further corroborating the 'extraordinary' findings of Sutton et al. (2008) and Fock and Ehrich (2010). There was a decrease in bathypelagic biomass between 1000-1900 m at night and an increase in mesopelagic biomass between 700-1000m (Fig. 8b). Qualitative examination suggests the possibility of a bathypelagic DVM. The daytime biomass catch rates between 1000-1900 m were double the nighttime catch rates. Although the samples sizes were different ( 8 day, 3 night), they were standardized for volume filtered. The lowest biomass/volume value for a daytime sample was equal to the pooled biomass/volume for all nighttime samples. Additionally, the increased mesopelagic (200- 
$700 \mathrm{~m}$ ) biomass at night, occurring at the same time that mesopelagic species migrated into the epipelagic zone, provides support to the notion of DVM from the bathypelagic zone (conservation of mass). However, an ANOVA did not reveal a significant difference in catch rates, day vs. night, at bathypelagic depths with respect to abundance or biomass $(P=0.94, P=0.17$, respectively, Fig. 16$)$. An alternate explanation of the increased catch rates during the day vs. night in bathypelagic depths could be differential catchability as a function of solar cycle, though midwater trawl catches at night are historically reported as being greater than catches during the day, ostensibly due to visual avoidance (Itaya et al. 2007). The possibility of DVM between the bathy- and mesopelagic zones, though not statistically proven here, seems the most parsimonious explanation. A discrete break between the mesopelagic and bathypelagic fauna at the $1000 \mathrm{~m}$ isobath does not hold true for all species. The vertical distributions of many species cross this boundary (Figs. 9a, $10 \mathrm{a}, 10 \mathrm{~b})$ and such species have recently been described by Sutton et al. (2010) as "spanners" or "vacillators." The factor generally invoked as the rationale for $1000 \mathrm{~m}$ as the dividing line between meso- and bathypelagic zones is solar light penetration (i.e., diel solar signal), which can vary based on location. The dividing line of $1000 \mathrm{~m}$ may not be as strong a factor in the CGFZ region of the North Atlantic in summertime due to enhanced surface productivity, sedimentation, and persistent cloud cover, all of which increase light attenuation.

Sutton et al. (2008) reported finding large numbers of Cyclothone microdon present in $0-200 \mathrm{~m}$ trawl samples, which was unusual due to previously reported distributions of this species in the North Atlantic being well below $500 \mathrm{~m}$ (Backus et al. 1969, Badcock 1984, Quéro et al. 1990a). Sutton et al. (2008) could not conclusively rule 
out contamination from the multiple codend system. The same trawl gear was used in this study and collected over 450 individuals of $C$. microdon from all seven 0-200 m trawl samples. In order to rule out net contamination as a cause for these shallow captures, one station (16, Fig. 3) located over a seamount was sampled to a maximum depth of $579 \mathrm{~m}$ over a mean bottom depth of $753 \mathrm{~m}$. In total, 876 individuals of $C$. microdon were collected from this station between 0-579 m, of which 59 were collected between 0-200 m. This finding appears to rule out net contamination by confirming the presence of $C$. microdon in depths shallower than $500 \mathrm{~m}$, at least above a seamount. Net contamination (trickle down from forenet) is a potential problem when using multiple codends, but it normally results in just a few individuals as opposed to the large numbers observed for $C$. microdon in this study (pers. observation).

Upwelling near the seamount at station 16 could explain the shallow presence of C. microdon at this station, but would not explain its presence in the other six $0-200 \mathrm{~m}$ samples. Whether its presence indicates a species vertical range extension, a passive migration, or an active (diel, seasonal, and/or ontogenetic) migration is still unknown. Opdal et al. (2008) noted the absence of schooling planktivorous fishes in the surface zone above the ridge and suggested that the epipelagic primary and secondary production chiefly supports a mesopelagic food-web. These authors suggested that the mesopelagic fish production could be limited by the amount of primary production through bottom-up control. The presence of bathypelagic taxa in the epipelagic could be attributed to the enhanced abundance of food and/or the decrease in competition. The lack of schooling planktivorous fishes coupled with the presence of the ridge shorten the food chain (at least the distance/steps between trophic levels), thereby increasing transfer efficiencies 
and total production of the deep-pelagic fauna. In addition to fishes, invertebrate taxonomists onboard the 2009 Bigelow expedition confirmed the captures of bathypelagic shrimps and squids in the top $200 \mathrm{~m}$, which further corroborates the findings that species distributions over the MAR differ from those of the open ocean.

\section{SUMMARY}

The region surrounding the CGFZ is characterized by dynamic hydrography, abrupt topography, and enhanced production spanning multiple trophic levels. Surface temperature, water masses, and deep-pelagic biodiversity all exhibit a gradient from the northwest side of the fracture zone to the southeast. These findings suggest two things: 1) the entire study area was encompassed by the Subpolar Front, preventing a complete answer to the original question regarding the SPF as a biogeographic barrier to deeppelagic species distributions; and 2) within the study area the SPF sets up a gradient of change in assemblages as opposed to a discrete boundary.

Evidence of diel vertical migration was found in the mesopelagic, and perhaps bathypelagic, zones, along with the unusual finding of bathypelagic taxa in the top 200 m. Additional sampling would be needed to conclusively determine if there is indeed diel vertical migration in the bathypelagic, thus supporting Vinogradov's (1968) 'ladder of migration' theory. Future efforts to investigate this theory should focus on a hydrographically stable region to improve confidence in station 'replication' for day and night sampling. Another important consideration would be to improve the opening/closing device controlling the multi-sampling unit to have real-time depth sensing which would standardize the depth zones sampled. The overall diel vertical 
distributions of deep-pelagic nekton in this region of the Mid-Atlantic Ridge differ from the "classical" open ocean paradigm, with deeper daytime biomass maxima and possible vertical movement by bathypelagic fauna. This may support the notion that the ecology over mid-ocean ridge systems reflects a unique type of pelagic habitat. 


\section{LITERATURE CITED}

Angel, M.V., 1985. Vertical migrations in the oceanic realm: possible causes and probable effects. Contributions in Marine Science 27 (Suppl.).

Angel, M.V., 1989. Vertical profiles of pelagic communities in the vicinity of the Azores Front and their implications to deep ocean ecology. Progress in Oceanography 22, 1-46.

Angel, M.V., 1993. Biodiversity of the pelagic ocean. Conservation Biology 7(4), 760772.

Angel, M.V., 1997. Pelagic biodiversity. In: Ormond, R.F.G., Gage, J.D., Angel, M.V. (Eds.), Marine Biodiversity: Patterns and Processes. Cambridge University Press, Cambridge, pp. 35-68.

Angel, M.V., Baker, A.C., 1982. Vertical distribution of the standing crop of plankton and micronekton at three stations in the northeast Atlantic. Biological Oceanography 2, 1-30.

Angel, M.V., Boxshall, G.A., 1990. Life in the benthic boundary layer connections to the mid-water and sea floor. Philosophical Transactions of the Royal Society of London, Series A 331, 15-28.

Angel, M.V., Pugh, P.R., 2000. Quantification of diel vertical migration by micronektonic taxa in the northeast Atlantic. Hydrobiologia 440, 161-179.

Backus, R.H., Clark, R.C., 1965. Behaviour of certain marine organisms during the solar eclipse of July 20, 1963. Nature 205, 989-991.

Backus, R.H., Craddock, J.E., Haedrich, R.L., Robison, B.H., 1977. Atlantic mesopelagic zoogeography. In: Fishes of the Western North Atlantic. Memoir, Sears Foundation for Marine Research, 1 (7), 266-287.

Backus, R.H., Craddock, J.E., Haedrich, R.L., Shores, D.L., 1969. Mesopelagic fishes and thermal fronts in the western Sargasso Sea. Marine Biology 3, 87-106.

Badcock, J., 1984. Gonostomatidae. In: Whitehead, P.J.P., Bauchot, M.-L., Hureau, J.-C., Nielsen, J., Tortonese, E. (Eds.), Fishes of the North-eastern Atlantic and the Mediterranean, vol. 1. UNESCO, Paris, pp. 284-301.

Bauchot, M.-L., 1986. Serrivomeridae. In: Whitehead, P.J.P., Bauchot, M.-L., Hureau, J.C., Nielsen, J., Tortonese, E. (Eds.), Fishes of the North-eastern Atlantic and the Mediterranean, vol. II. UNESCO, Paris, pp. 548-550. 
Bergstad, O.A., 1990. Ecology of the fishes of the Norwegian Deep: distribution and species assemblages. Netherlands Journal of Sea Research 25, 237-266.

Bergstad, O.A., Falkenhaug, T., Astthorsson, O.S., Byrkjedal, I., Gebruk, A.V., Piatkowski, U., Priede, I.G., Santos, R.S., Vecchione, M., Lorance, P., Gordon, J.D.M., 2008. Towards improved understanding of the diversity and abundance patterns of the mid-ocean ridge macro- and megafauna. Deep-Sea Research Part II 55, 1-5.

Bergstad, O.A., Godø, O.R., 2003. The pilot project "Patterns and processes of the ecosystems of the northern Mid-Atlantic": aims, strategy, and status. Oceanologica Acta 25, 219-226.

Bollens, S.M., Frost, B.W., Thoreson, D.S., Watts, S.J., 1992. Diel vertical migration in zooplankton: field evidence in support of the predator avoidance hypothesis. Hydrobiologia 234, 33-39.

Bower, A.S., Le Cann, B., Rossby, T., Zenk, W., Gould, J., Speer, K., Richardson, P., Prater, M.D., Zhang, H.M., 2002. Directly measured circulation in the northeastern North Atlantic Ocean. Nature 419, 603-607.

Bower, A.S., von Appen, W-J., 2008. Interannual variability in the pathways of the North Atlantic Current over the Mid-Atlantic Ridge in the impact of topography. Journal of Physical Oceanography 38, 104-120.

Bray, J.R., Curtis, J.T., 1957. An ordination of the upland forest communities of Southern Wisconsin. Ecological Monographs 27, 325-349.

Busch, S., Johnson, B.M., Mehner, T., 2011. Energetic costs and benefits of cyclic habitat switching: a bioenergetics model analysis of diel vertical migration in coregonids. Canadian Journal of Fisheries and Aquatic Sciences 68 (4), 706-717.

Clark, D.R., Aazem, K.V., Hays, G.C., 2001. Zooplankton abundance and community structure over a $4000 \mathrm{~km}$ transect in the north-east Atlantic. Journal of Plankton Research 23, 365-372.

Clarke, G.L., Denton, E.J., 1962. Light and animal life. In: Hill, M.N. (Ed.), The Sea. Vol. 1. Interscience, New York, pp. 456-468.

Clarke, K.R., Gorley, R.N., 2006. PRIMER v6: User Manual/Tutorial. PRIMER-E, Plymouth. 
Cohen, J.H., Forward, Jr., R.B., 2009. Zooplankton diel vertical migration - a review of proximate control. In: Gibson, R.N., Atkinson, R.J.A., Gordon, J.D.M. (Eds.), Oceanography and Marine Biology: An Annual Review. Vol. 47. CRC Press, Boca Raton, pp 77-109.

Craddock, J.E., Hartel, K.E., Flescher, D., 2002. Lanternfishes: order myctophiformes. In: Collette, B.B., Klein-MacPhee, G. (Eds.), Fishes of the Gulf of Maine, pp. 198-204.

Cushing, D.H., 1951. Vertical migration of planktonic crustacea. Biological Reviews of the Cambridge Philosophical Society 26(2), 158-192.

Cushing, D.H., Walsh, J.J. (Eds.), 1976. The ecology of the seas. W.B. Saunders Company, Philadelphia, PA.

Cuvier, G., 1817. La règne animale. Paris.

Dam, H.G., Zhang, X., Butler, M., Roman, M.R., 1995. Mesozooplankton grazing and metabolism at the equator in the central Pacific: implications for carbon and nitrogen fluxes. Deep-Sea Research II 42(2-3), 735-756.

Ducklow, H.W., Steinberg, D.K., Buesseler, K.O., 2001. Upper ocean carbon export and the biological pump. Oceanography 14(4), 50-58.

Esterly, C.O., 1912. The occurrence and vertical distribution of the Copepoda of the San Diego region with particular reference to nineteen species. University of California Publications in Zoology 9, 253.

Faith, D.P., Minchin, P.R., Belbin, L., 1987. Compositional dissimilarity as a robust measure of ecological distance. Vegetatio 69, 57-68.

Fock, H.O., Ehrich, S., 2010. Deep-sea pelagic nekton biomass estimates in the North Atlantic: horizontal and vertical resolution of revised data from 1982 and 1983. Journal of Applied Ichthyology 26, 85-101.

Forward, Jr., R.B., Tankersley, R.A., Burke, J.S., 1996. Endogenous swimming rhythms of larval Atlantic menhaden, Brevoortia tyrannus Latrobe: implications for vertical migration. Journal of Experimental Marine Biology and Ecology 204, 195-207.

Fossen, I., Cotton, C.F., Bergstad, O.A., Dyb, J.E. 2008. Species composition and distribution patterns of fishes captured by longlines on the Mid-Atlantic Ridge. Deep-Sea Research II 55, 203-217. 
Gaard, E., Gislason, A., Falkenhaug, T., Søiland, H., Musaeva, E., Vereshchaka, A., Vinogradov, G., 2008. Horizontal and vertical copepod distribution and abundance on the Mid-Atlantic Ridge in June 2004. Deep-Sea Research II 55, 5971.

Gallienne, C.P., Robins, D.B., Woodd-Walker, R.S. 2001. Abundance, distribution, and size structure of zooplankton along a $20^{\circ}$ west meridional transect of the northeast Atlantic Ocean in July. Deep-Sea Research II 48, 925-949.

Gislason, A. 2003. Life-cycle strategies and seasonal migrations of oceanic copepods in the Irminger sea. Hydrobiologia 503, 195-209.

Gislason, A., Gaard, E., Debes, H., Falkenhaug, T., 2008. Abundance, feeding and reproduction of Calanus finmarchicus in the Irminger Sea and on the northern Mid-Atlantic Ridge in June. Deep-Sea Research II 55, 72-82.

Halliday, R.G., 1970. Growth and vertical distribution of the Glacier Lanternfish, Benthosema glaciale, in the northwestern Atlantic. Journal of the Fisheries Research Board of Canada 27, 105-116.

Harris, J.E., 1963. The role of endogenous rhythms in vertical migration. Journal of the Marine Biological Association of the United Kingdom 43, 153-166.

Hays, G.C., 1996. Large-scale patterns of diel vertical migration in the North Atlantic. Deep-Sea Research 43, 1601-1615.

Herring, P., 2004. The biology of the deep ocean. Oxford University Press, New York, NY.

Hosia, A., Stemmann, L., Youngbluth, M. 2008. Distribution of net-collected planktonic cnidarians along the northern Mid-Atlantic Ridge and their associations with the main water masses. Deep-Sea Research II 55, 106-118.

Hulley, P.A., 1984. Myctophidae. In: Whitehead, P.J.P., Bauchot, M.-L., Hureau, J.-C., Nielsen, J., Tortonese, E. (Eds.), Fishes of the North-eastern Atlantic and the Mediterranean, vol. 1. UNESCO, Paris, pp. 429-483.

Huntley, M., Brooks, E.R., 1982. Effects of age and food availability on diel vertical migration of Calanus pacificus. Marine Biology 71, 23-31.

Itaya, K., Fujimori, Y., Shimizu, S., Komatsu, T., Miura, T., 2007. Effect of towing speed and net mouth size on catch efficiency in framed midwater trawls. Fisheries Science 73, 1007-1016. 
Kruskal, J.B., Wish, M., 1978. Multidimensional scaling. Sage Publications, Beverley Hills, California.

Lampert, W., 1989. The adaptive significance of diel vertical migration of zooplankton. Functional Ecology 3, 21-27.

Longhurst, A.R., 1976. Vertical Migration. In: Cushing, D.H., Walsh, J.J. (Eds.), The ecology of the seas. W.B. Saunders Company, Philadelphia, PA, pp. 116-137.

Longhurst, A.R., Bedo, A.W., Harrison, W.G., Head, E.J.H., Sameoto, D.D., 1990. Vertical flux of respiratory carbon by oceanic diel migrant biota. Deep-Sea Research 37(4), 685-694.

Longhurst, A.R., Harrison, W.G., 1988. Vertical nitrogen flux from the oceanic photic zone by diel migrant zooplankton and nekton. Deep-Sea Research 35(6), 881-889.

Marshall, N.B., 1971. Explorations in the life of fishes. Harvard University Press, Cambridge, MA.

Mauchline, J., 1988. Growth and breeding of meso- and bathypelagic organisms of the Rockall Trough, northeastern Atlantic Ocean and evidence of seasonality. Marine Biology 98, 387-393.

Opdal, A.F., Godø, O.R., Bergstad, O.A., Fiksen, Ø. 2008. Distribution, identity, and possible processes sustaining meso- and bathypelagic scattering layers on the northern Mid-Atlantic Ridge. Deep-Sea Research II, 55, 45-58.

Owen, R.W., 1981. Fronts and eddies in the sea: mechanisms, interactions, and biological effects. In: Longhurst, A.R. (Ed.), Analysis of Marine Ecosystems. Academic Press, London, pp.197-233.

Pearre, S. 2003. Eat and run? The hunger/satiation hypothesis in vertical migration: history, evidence and consequences. Biological Reviews 78, 1-79.

Pierrot-Bults, A. 2008. A short note on the biogeographic patterns of the Chaetognatha fauna in the North Atlantic. Deep-Sea Research II 55, 137-141.

Porteiro, F.M., Sutton, T.T., 2007. Midwater fish assemblages and seamounts. In: Pitcher, T.J., Morato, T., Hart, P.J.B., Clark, M.R., Haggan, N., Santos, R.S. (Eds.), Seamounts: Ecology, Fisheries, and Conservation. Blackwell Publishing, Oxford, pp. 101-116. 
Priede, I.G., Bergstad, O.A., Miller, P.I., Vecchione, M., Gebruk, A., Falkenhaug, T., Billett, D.S.M., Craig, J., Dale, A.C., Shields, M.A., Sutton, T.T., Gooday, A.J., Inall, M.E., Jones, D.O.B., Martinez-Vincente, V., Menezes, G.M., Niedzielski, T., Tilstone, G.H., Sigurðsson, P., Rothe, N., Rogacheva, A., Alt, C., Brand, T., Abell, R., Brierley, A.S., Cousins, N.J., Crockard, F., Hoelzel, A.R., Høines, Å., Letessier, T.B., Read, J.F., Shimmield, T., Cox, M.J., Galbraith, J.K., Gordon, J.D.M., Horton, T., Neat, F., Lorance, P., submitted. The significance of the northern Mid-Atlantic Ridge in basin-scale oceanic ecology. Science.

Quéro, J.-C., Njock, J.C., de la Hoz, M.M., 1990a. Gonostomatidae. In: Quéro, J.-C., Hureau, J.C., Karrer, C., Post, A., Saldanha, L. (Eds.), Check-list of the Fishes of the Eastern Tropical Atlantic (CLOFETA), vol. 1. JNICT, Lisbon; SEI, Paris; and UNESCO, Paris, pp. 283-292.

Quéro, J.-C., Njock, J.C., de la Hoz, M.M., 1990b. Sternoptychidae. In: Quéro, J.-C., Hureau, J.C., Karrer, C., Post, A., Saldanha, L. (Eds.), Check-list of the Fishes of the Eastern Tropical Atlantic (CLOFETA), vol. 1. JNICT, Lisbon; SEI, Paris; and UNESCO, Paris, pp. 278, 279.

Read, J.F., Pollard, R.T., Miller, P.I., Dale, A.C., 2010. Circulation variability of the North Atlantic Current in the vicinity of the Mid-Atlantic Ridge. Deep-Sea Research I 57, 307-318.

Robinson, C., Steinberg, D.K., Anderson, T.R., Arístegui, J., Carlson, C.A., Frost, J.R., Ghiglione, J-F., Hernández-León, S., Jackson, G.A., Koppelmann, R., Quéguiner, B., Ragueneau, O., Rassoulzadegan, F., Robison, B.H., Tamburini, C., Tanaka, T., Wishner, K.F., Zhang, J., 2010. Mesopelagic zone ecology and biogeochemistry a synthesis. Deep-Sea Research II 57, 1504-1518.

Robison, B.H., 2004. Deep pelagic biology. Journal of Experimental Marine Biology and Ecology 300, 253-272.

Romesburg, H.C., 1990. Cluster Analysis for Researchers. Robert E. Kreiger Publishing Company, Malabar, FL.

Rossby, T., 1999. On gyre interaction. Deep-Sea Research II 46, 139-164.

Russell, F.S., 1927. The vertical distribution of plankton in the sea. Biological Reviews 2, 213.

Skov, H., Gunnlaugsson, T., Budgell, W.P., Horne, J., Nøttestad, L., Olsen, E., Søiland, H., Vikingsson, G., Waring, G. 2008. Small-scale spatial variability of sperm and sei whales in relation to oceanographic and topographic features along the MidAtlantic Ridge. Deep-Sea Research II 55, 254-268. 
Søiland, H., Budgell, P., Knutsen, Ø., 2008. The physical oceanographic conditions along the Mid-Atlantic Ridge north of the Azores in June-July 2004. Deep-Sea Research II 55, 29-44.

Steinberg, D.K., Carlson, C.A., Bates, N.R., Goldthwait, S.A., Madin, L.P., Michaels, A.F., 2000. Zooplankton vertical migration and the active transport of dissolved organic and inorganic carbon in the Sargasso Sea. Deep-Sea Research I 47, 137 158.

Stemmann, L., Hosia, H., Youngbluth, J.M.A., Søiland, H., Picheral, M., Gorsky, G. 2008. Vertical distribution (0-1000 m)of macrozooplankton, estimated using the Underwater Video Profiler, in different hydrographic regimes along the northern portion of the Mid-Atlantic Ridge. Deep-Sea Research II 55, 94-105.

Sutton, T.T., Porteiro, F.M., Heino, M., Byrkjedal, I., Langhelle, G., Anderson, C.I.H., Horne, J., Søiland, H., Falkenhaug, T., Godø, O.R., Bergstad, O.A., 2008. Vertical structure, biomass and topographic association of deep-pelagic fishes in relation to a mid-ocean ridge system. Deep-Sea Research II 55, 161-184.

Sutton, T.T., Wiebe, P.H., Madin, L., Bucklin, A., 2010. Diversity and community structure of pelagic fishes to $5000 \mathrm{~m}$ depth in the Sargasso Sea. Deep-Sea Research II 57, 2220-2233.

Sy, A., 1988. Investigation of large-scale circulation patterns in the central North Atlantic: the North Atlantic Current, the Azores Current, and the Mediterranean Water plume in the area of the Mid-Atlantic Ridge. Deep-Sea Research 35, 383413.

Sy, A., Schauer, U., Meincke, J., 1992. The North Atlantic Current and its associated hydrographic structure above and eastwards of the Mid-Atlantic Ridge. Deep-Sea Research 39, 825-853.

Vecchione, M., Bergstad, O.A., Byrkjedal, I., Falkenhaug, T., Gebruk, A.V., Godø, O.R., Gislason, A., Heino, M., Høines, A.S., Menezes, G.M.M., Piatkowski, U., Priede, I.G., Skov, H., Søiland, H., Sutton, T.T., Wenneck, T. de L., 2010a. Biodiversity patterns and processes on the Mid-Atlantic Ridge. In: McIntyre, A.D. (Ed.), Life in the World's Oceans; Diversity, Distribution, and Abundance. Blackwell Publishing Ltd., Oxford, pp. 103-121.

Vecchione, M., Young, R.E., Piatkowski, U., 2010b. Cephalopods of the northern MidAtlantic Ridge. Marine Biology Research 6, 25-52.

Vinogradov, M.E., 1953. The role of vertical migrations of the zooplankton in the feeding of deep-sea animals. Priroda 6, 95-96. 
Vinogradov, M.E., 1968. Vertical Distribution of the Oceanic Zooplankton. Academy of Science of the U.S.S.R., Institut of Oceanography. In Russian, translated by Israel Program for Scientific Translation Ltd., Keter Press, Jerusalem, 1970.

Webb, T.J., Vanden Berghe, E., O'Dor, R., 2010. Biodiversity's big wet secret: The global distribution of marine biological records reveals chronic under-exploration of the deep pelagic ocean. PLoS One 5(8), e10223. doi: 10.1371/journal.pone.0010223.

Wenneck, T. de L., Falkenhaug, T., Bergstad, O.A., 2008. Strategies, methods, and technologies adopted on the R.V. G.O. Sars MAR-ECO expedition to the MidAtlantic Ridge in 2004. Deep-Sea Research Part II 55, 6-28.

Williamson, C.E., Fischer, J.M., Bollens, S.M., Overholt, E.P., Breckenridge, J.K., 2011. Toward a more comprehensive theory of zooplankton diel vertical migration: integrating ultraviolet radiation and water transparency into the biotic paradigm. Limnology and Oceanography 56 (5), 1603-1623.

Youngbluth, M., Sørnes, T., Hosia, A., Stemmann, L. 2008. Vertical distribution and relative abundance of gelatinous zooplankton, in situ observations near the MidAtlantic Ridge. Deep-Sea Research II 55, 119-125.

Zhang, X., Dam, H.G., 1997. Downward export of carbon by diel migrant mesozooplankton in the central equatorial Pacific. Deep-Sea Research II 44, 2191-2202. 
Table 1. Trawl data from the 2009 Henry B. Bigelow MAR-ECO expedition used for deep-pelagic fish vertical distribution analysis and solar cycle analysis.

\begin{tabular}{|c|c|c|c|c|c|c|c|c|c|c|}
\hline Sta & $\begin{array}{l}\text { Sample } \\
\text { code }\end{array}$ & $\begin{array}{c}\text { Date } \\
(2009)\end{array}$ & $\begin{array}{l}\text { Latitude } \\
\left({ }^{\circ} \mathrm{N}\right)\end{array}$ & $\begin{array}{l}\text { Longitude } \\
\left({ }^{\circ} \mathrm{W}\right)\end{array}$ & $\begin{array}{c}\text { Mean } \\
\text { bottom } \\
\text { depth } \\
\text { (m) }\end{array}$ & $\begin{array}{c}\text { Max } \\
\text { trawl } \\
\text { depth } \\
\text { (m) }\end{array}$ & $\begin{array}{c}\text { Min } \\
\text { trawl } \\
\text { depth } \\
\text { (m) }\end{array}$ & $\begin{array}{l}\text { Depth } \\
\text { zone }\end{array}$ & $\begin{array}{l}\text { Solar } \\
\text { cycle }\end{array}$ & $\begin{array}{l}\text { Filtered } \\
\text { Volume } \\
\left(\mathrm{m}^{3}\right)\end{array}$ \\
\hline 9 & 0901 & 21-Jun & $53^{\circ} 22^{\prime}$ & $36^{\circ} 47^{\prime}$ & 3055 & 2799 & 2702 & 4 & $\mathrm{~N}$ & 123107 \\
\hline 9 & 0902 & 21-Jun & $53^{\circ} 23^{\prime}$ & $36^{\circ} 46^{\prime}$ & 3055 & 2702 & 1864 & 4 & $\mathrm{~N}$ & 152951 \\
\hline 9 & 0903 & 21-Jun & $53^{\circ} 25^{\prime}$ & $36^{\circ} 46^{\prime}$ & 3055 & 1864 & 719 & 3 & $\mathrm{~N}$ & 154417 \\
\hline 9 & 0904 & 21-Jun & $53^{\circ} 26^{\prime}$ & $36^{\circ} 47^{\prime}$ & 3055 & 719 & 101 & 2 & ND & 121303 \\
\hline 9 & 0905 & 21-Jun & $53^{\circ} 28^{\prime}$ & $36^{\circ} 47^{\prime}$ & 3055 & 101 & 0 & 1 & ND & 37172 \\
\hline 11 & 1102 & 21-Jun & $53^{\circ} 15^{\prime}$ & $35^{\circ} 32^{\prime}$ & 2548 & 1405 & 1359 & 3 & $\mathrm{~N}$ & 132486 \\
\hline 11 & 1103 & 21-Jun & $53^{\circ} 17^{\prime}$ & $35^{\circ} 33^{\prime}$ & 2548 & 1375 & 663 & 3 & $\mathrm{~N}$ & 152432 \\
\hline 11 & 1104 & 21-Jun & $53^{\circ} 18^{\prime}$ & $35^{\circ} 33^{\prime}$ & 2548 & 663 & 161 & 2 & $\mathrm{~N}$ & 106214 \\
\hline 11 & 1105 & 21-Jun & $53^{\circ} 20^{\prime}$ & $35^{\circ} 34^{\prime}$ & 2548 & 161 & 5 & 1 & $\mathrm{~N}$ & 37724 \\
\hline 12 & 1202 & 22-Jun & $52^{\circ} 58^{\prime}$ & $34^{\circ} 57^{\prime}$ & 1650 & 1600 & 1542 & 3 & D & 129375 \\
\hline 12 & 1203 & 22-Jun & $52^{\circ} 57^{\prime}$ & $35^{\circ} 01^{\prime}$ & 1650 & 1578 & 894 & 3 & D & 153934 \\
\hline 12 & 1204 & 22-Jun & $52^{\circ} 57^{\prime}$ & $35^{\circ} 03^{\prime}$ & 1650 & 894 & 157 & $2 / 3$ & D & 122294 \\
\hline 12 & 1205 & 22-Jun & $52^{\circ} 57^{\prime}$ & $35^{\circ} 06^{\prime}$ & 1650 & 157 & 2 & 1 & D & 35009 \\
\hline 13 & 1302 & 22-Jun & $53^{\circ} 09^{\prime}$ & $34^{\circ} 46^{\prime}$ & 2350 & 1493 & 583 & 3 & DN & 189931 \\
\hline 13 & 1303 & 22-Jun & $53^{\circ} 11^{\prime}$ & $34^{\circ} 46^{\prime}$ & 2350 & 583 & 0 & 2 & DN & 141282 \\
\hline 14 & 1402 & 23-Jun & $53^{\circ} 08^{\prime}$ & $34^{\circ} 46^{\prime}$ & 2350 & 1477 & 1352 & 3 & $\mathrm{~N}$ & 128205 \\
\hline 14 & 1403 & 23-Jun & $53^{\circ} 06^{\prime}$ & $34^{\circ} 45^{\prime}$ & 2350 & 1477 & 887 & 3 & $\mathrm{~N}$ & 153082 \\
\hline 14 & 1404 & 23-Jun & $53^{\circ} 04^{\prime}$ & $34^{\circ} 45^{\prime}$ & 2350 & 887 & 308 & $2 / 3$ & ND & 96597 \\
\hline 14 & 1405 & 23-Jun & $53^{\circ} 03^{\prime}$ & $34^{\circ} 45^{\prime}$ & 2350 & 308 & 91 & 1 & ND & 42420 \\
\hline 15 & 1501 & 23-Jun & $53^{\circ} 01^{\prime}$ & $33^{\circ} 34^{\prime}$ & 3030 & 2903 & 2769 & 4 & $\mathrm{D}$ & 139543 \\
\hline 15 & 1502 & 23-Jun & $53^{\circ} 00^{\prime}$ & $33^{\circ} 32^{\prime}$ & 3030 & 2769 & 1943 & 4 & D & 171727 \\
\hline 15 & 1503 & 23-Jun & $52^{\circ} 59^{\prime}$ & $33^{\circ} 29^{\prime}$ & 3030 & 1943 & 903 & 3 & D & 171546 \\
\hline 15 & 1504 & 23-Jun & $52^{\circ} 58^{\prime}$ & $33^{\circ} 26^{\prime}$ & 3030 & 903 & 232 & $2 / 3$ & D & 133305 \\
\hline 15 & 1505 & 23-Jun & $52^{\circ} 57^{\prime}$ & $33^{\circ} 24^{\prime}$ & 3030 & 232 & 1 & 1 & D & 49038 \\
\hline 16 & 1602 & 24-Jun & $52^{\circ} 16^{\prime}$ & $31^{\circ} 00^{\prime}$ & 753 & 579 & 492 & 2 & $\mathrm{~N}$ & 130892 \\
\hline 16 & 1603 & 24-Jun & $52^{\circ} 17^{\prime}$ & $30^{\circ} 57^{\prime}$ & 753 & 492 & 408 & 2 & $\mathrm{~N}$ & 39930 \\
\hline 16 & 1604 & 24-Jun & $52^{\circ} 17^{\prime}$ & $30^{\circ} 56^{\prime}$ & 753 & 408 & 206 & 2 & $\mathrm{~N}$ & 43123 \\
\hline 16 & 1605 & 24-Jun & $52^{\circ} 17^{\prime}$ & $30^{\circ} 56^{\prime}$ & 753 & 206 & 1 & 1 & $\mathrm{~N}$ & 42761 \\
\hline 17 & 1701 & 24-Jun & $51^{\circ} 32^{\prime}$ & $30^{\circ} 57^{\prime}$ & 3461 & 2715 & 2501 & 4 & D & 148260 \\
\hline 17 & 1702 & 24-Jun & $51^{\circ} 30^{\prime}$ & $30^{\circ} 56^{\prime}$ & 3461 & 2501 & 1817 & 4 & D & 178760 \\
\hline 17 & 1703 & 24-Jun & $51^{\circ} 28^{\prime}$ & $30^{\circ} 56^{\prime}$ & 3461 & 1817 & 1262 & 3 & D & 173894 \\
\hline 17 & 1704 & 24-Jun & $51^{\circ} 26^{\prime}$ & $30^{\circ} 56^{\prime}$ & 3461 & 1262 & 552 & $2 / 3$ & D & 128681 \\
\hline 17 & 1705 & 24-Jun & $51^{\circ} 25^{\prime}$ & $30^{\circ} 56^{\prime}$ & 3461 & 552 & 238 & 2 & D & 52780 \\
\hline 18 & 1802 & 24-Jun & $51^{\circ} 55^{\prime}$ & $30^{\circ} 24^{\prime}$ & 1910 & 1448 & 1175 & 3 & D & 130480 \\
\hline 18 & 1803 & 24-Jun & $51^{\circ} 56^{\prime}$ & $30^{\circ} 22^{\prime}$ & 1910 & 1448 & 1088 & 3 & $\mathrm{~N}$ & 399383 \\
\hline 18 & 1804 & 24-Jun & $51^{\circ} 58^{\prime}$ & $30^{\circ} 21^{\prime}$ & 1910 & 1088 & 460 & $2 / 3$ & $\mathrm{~N}$ & 132308 \\
\hline 18 & 1805 & 24-Jun & $51^{\circ} 59^{\prime}$ & $30^{\circ} 20^{\prime}$ & 1910 & 460 & 247 & 2 & $\mathrm{~N}$ & 50414 \\
\hline
\end{tabular}




\begin{tabular}{|c|c|c|c|c|c|c|c|c|c|c|}
\hline Sta & $\begin{array}{l}\text { Sample } \\
\text { code }\end{array}$ & $\begin{array}{l}\text { Date } \\
(2009)\end{array}$ & $\begin{array}{l}\text { Latitude } \\
\left({ }^{\circ} \mathrm{N}\right)\end{array}$ & $\begin{array}{l}\text { Longitude } \\
\left({ }^{\circ} \mathrm{W}\right)\end{array}$ & $\begin{array}{c}\text { Mean } \\
\text { bottom } \\
\text { depth } \\
\text { (m) }\end{array}$ & $\begin{array}{l}\text { Max } \\
\text { trawl } \\
\text { depth } \\
(\mathrm{m})\end{array}$ & $\begin{array}{l}\text { Min } \\
\text { trawl } \\
\text { depth } \\
(\mathrm{m})\end{array}$ & $\begin{array}{l}\text { Depth } \\
\text { zone }\end{array}$ & $\begin{array}{l}\text { Solar } \\
\text { cycle }\end{array}$ & $\begin{array}{c}\text { Filtered } \\
\text { Volume } \\
\text { (m3) }\end{array}$ \\
\hline 19 & 1902 & 25-Jun & $51^{\circ} 35^{\prime}$ & $30^{\circ} 22^{\prime}$ & 1263 & 1159 & 1058 & 3 & D & 124705 \\
\hline 19 & 1903 & 25-Jun & $51^{\circ} 33^{\prime}$ & $30^{\circ} 22^{\prime}$ & 1263 & 1155 & 760 & 3 & D & 93546 \\
\hline 19 & 1904 & 25-Jun & $51^{\circ} 32^{\prime}$ & $30^{\circ} 22^{\prime}$ & 1263 & 760 & 201 & 2 & D & 123430 \\
\hline 19 & 1905 & 25-Jun & $51^{\circ} 30^{\prime}$ & $30^{\circ} 23^{\prime}$ & 1263 & 201 & 43 & 1 & D & 44846 \\
\hline 20 & 2002 & 25-Jun & $51^{\circ} 42^{\prime}$ & $29^{\circ} 26^{\prime}$ & 1916 & 1411 & 1287 & 3 & D & 144340 \\
\hline 20 & 2003 & 25-Jun & $51^{\circ} 43^{\prime}$ & $29^{\circ} 23^{\prime}$ & 1916 & 1414 & 1161 & 3 & D & 97474 \\
\hline 20 & 2004 & 25-Jun & $51^{\circ} 43^{\prime}$ & $29^{\circ} 21^{\prime}$ & 1916 & 1161 & 525 & $2 / 3$ & D & 122477 \\
\hline 20 & 2005 & 25-Jun & $51^{\circ} 44^{\prime}$ & $29^{\circ} 19^{\prime}$ & 1916 & 525 & 275 & 2 & D & 46588 \\
\hline 21 & 2101 & 26-Jun & $51^{\circ} 18^{\prime}$ & $28^{\circ} 51^{\prime}$ & 3512 & 2645 & 2540 & 4 & $\mathrm{~N}$ & 140112 \\
\hline 21 & 2102 & 26-Jun & $51^{\circ} 19^{\prime}$ & $28^{\circ} 52^{\prime}$ & 3512 & 2540 & 1905 & 4 & $\mathrm{~N}$ & 169855 \\
\hline 21 & 2103 & 26-Jun & $51^{\circ} 21^{\prime}$ & $28^{\circ} 55^{\prime}$ & 3512 & 1905 & 1132 & 3 & D & 171768 \\
\hline 21 & 2104 & 26-Jun & $51^{\circ} 22^{\prime}$ & $28^{\circ} 58^{\prime}$ & 3512 & 1132 & 596 & 3 & D & 123012 \\
\hline 21 & 2105 & 26-Jun & $51^{\circ} 22^{\prime}$ & $29^{\circ} 01^{\prime}$ & 3512 & 596 & 397 & 2 & D & 46768 \\
\hline
\end{tabular}


Table 2. Characterization of temperature profiles into hydrographic regimes in the CGFZ study area. "Hydrographic regions" are based on parameters described by Søiland et al. (2008).

\begin{tabular}{|c|c|c|c|c|}
\hline $\begin{array}{l}\text { Hydrographic } \\
\text { Regime: }\end{array}$ & 1 & $1 b$ & 2 & 3 \\
\hline Stations & $9,11,12,13 / 14,15$ & 16,18 & $17,19,20$ & 21 \\
\hline Temperature at: $0 \mathrm{~m}$ & $\leq 9^{\circ} \mathrm{C}$ & $10-11^{\circ} \mathrm{C}$ & $11-12^{\circ} \mathrm{C}$ & $>12^{\circ} \mathrm{C}$ \\
\hline $200 \mathrm{~m}$ & $5-6^{\circ} \mathrm{C}$ & $\sim 6^{\circ} \mathrm{C}$ & $\sim 7^{\circ} \mathrm{C}$ & $>8^{\circ} \mathrm{C}$ \\
\hline $700 \mathrm{~m}$ & $\leq 4^{\circ} \mathrm{C}$ & $\sim 4.2^{\circ} \mathrm{C}$ & $\sim 4.5^{\circ} \mathrm{C}$ & $>4.5^{\circ} \mathrm{C}$ \\
\hline $\begin{array}{l}\text { Søiland et al.'s } \\
\text { "Hydrographic } \\
\text { Regions": }\end{array}$ & \multicolumn{2}{|l|}{ SAIW } & \multicolumn{2}{|c|}{ Frontal } \\
\hline
\end{tabular}


Table 3. Species richness $(S)$ and mean Shannon diversity indices $\left(H^{\prime}, \mathrm{SD}=\right.$ standard deviation) including sampling effort per depth zone. Sample no. $=$ total number of samples, $S=$ species richness, $N=$ pooled number of individuals collected in depth zone, $V=$ pooled volume filtered in depth zone.

\begin{tabular}{lccccc}
\hline Depth Zone & $S$ & $H^{\prime}(\mathrm{SD})$ & Sample no. & $N$ & $V\left(\mathrm{~m}^{3}\right)$ \\
\hline $0-200 \mathrm{~m}$ & 18 & $1.78(0.46)$ & 7 & 1,256 & 297,228 \\
$200-700 \mathrm{~m}$ & 33 & $2.22(0.38)$ & 10 & 3,299 & 783,198 \\
$700-1900 \mathrm{~m}$ & 56 & $2.42(0.45)$ & 17 & 8,882 & $2,709,339$ \\
$1900-2900 \mathrm{~m}$ & 14 & $1.38(0.21)$ & 8 & 1,962 & 756,682 \\
\hline
\end{tabular}


Table 4. Integrated indices of diversity per sampling station. $S=$ species richness, $H^{\prime}=$ Shannon diversity index. "Hydrographic regions" are based on parameters described by Søiland et al. (2008). Geographic regions as previously described.

\begin{tabular}{ccccc}
\hline Station & S & $H^{\prime}$ & $\begin{array}{c}\text { Søiland et al.'s } \\
\text { "Hydrographic Region” }\end{array}$ & Geographic Region \\
\hline 9 & 19 & 2.79 & SAIW & NW \\
11 & 24 & 2.98 & SAIW & NW \\
12 & 16 & 2.59 & SAIW & NW \\
$13 / 14$ & 23 & 2.96 & SAIW & NW \\
15 & 25 & 3.07 & SAIW & NW \\
16 & 15 & 2.57 & SAIW & SE \\
17 & 24 & 3.04 & FRONTAL & SE \\
18 & 31 & 3.28 & SAIW & SE \\
19 & 30 & 3.28 & FRONTAL & SE \\
20 & 32 & 3.32 & FRONTAL & SE \\
21 & 30 & 3.27 & FRONTAL & \\
\hline
\end{tabular}




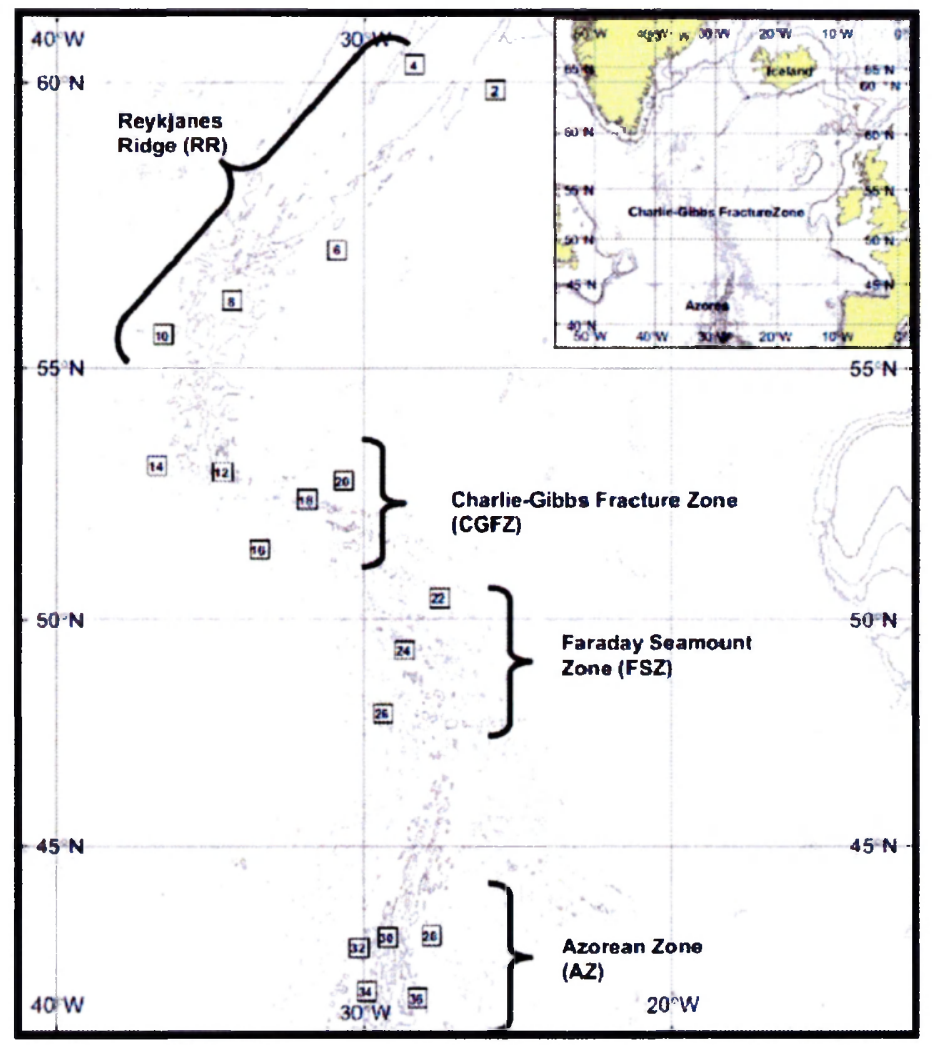

Figure 1. Trawl sampling stations for Leg 1 of the 2004 R/V G.O. Sars MAR-ECO expedition (after Sutton et al. 2008). 


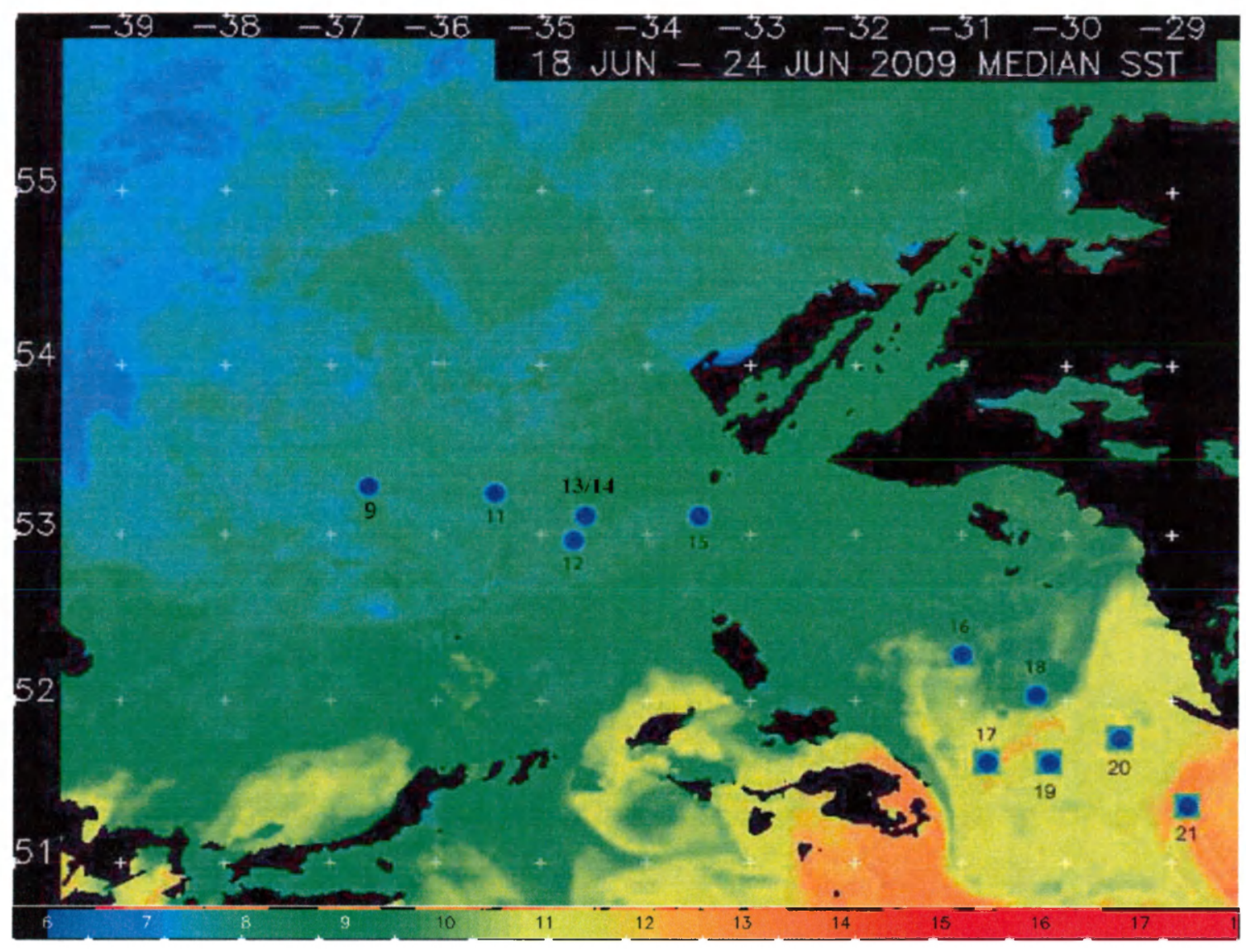

Figure 2. Trawl sampling stations of the $2009 \mathrm{R} / \mathrm{V}$ Henry B. Bigelow MAR-ECO expedition plotted on a weekly composite satellite image of sea-surface temperature $\left({ }^{\circ} \mathrm{C}\right)$. Black areas represent persistent cloud cover. Satellite image courtesy of NERC Earth Observation Data Acquisition and Analysis Service. 


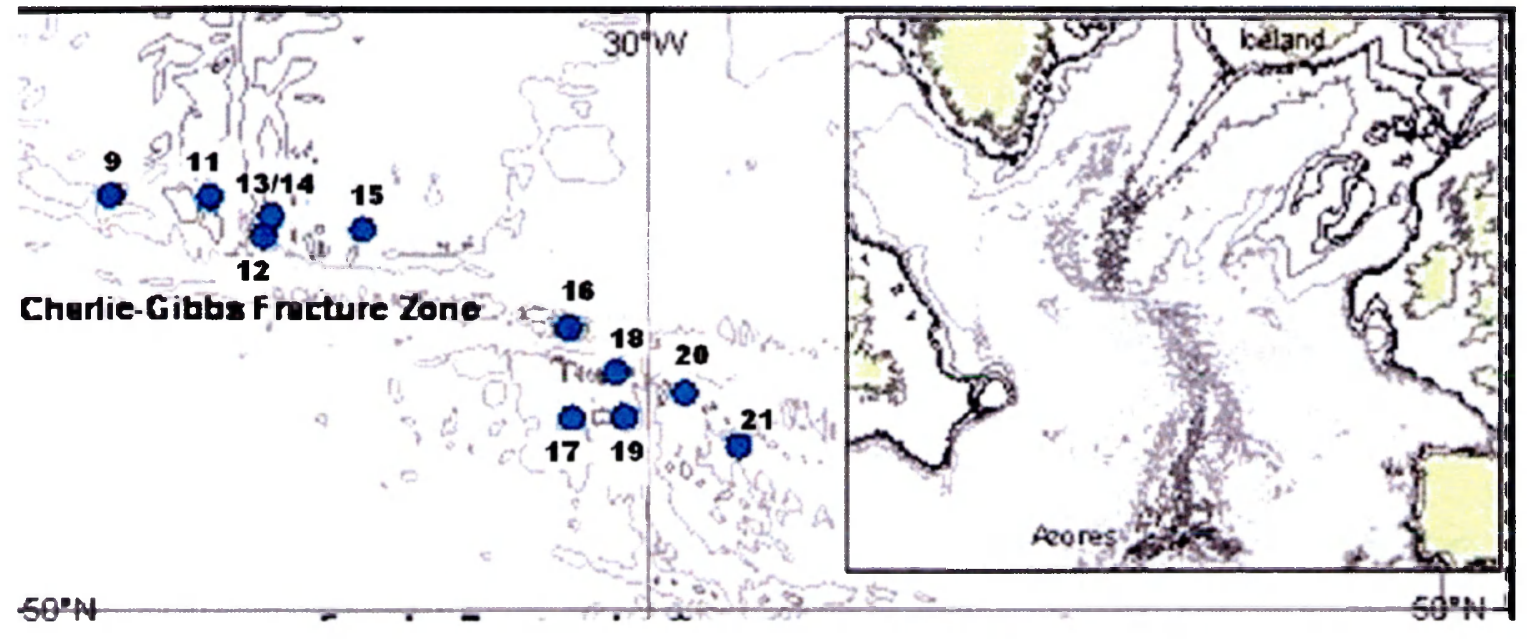

Figure 3. Study area and trawl sampling stations of the $2009 \mathrm{R} / \mathrm{V}$ Henry B. Bigelow MAR-ECO expedition. Box at right shows the northern Mid-Atlantic Ridge with offset at CGFZ in center. 


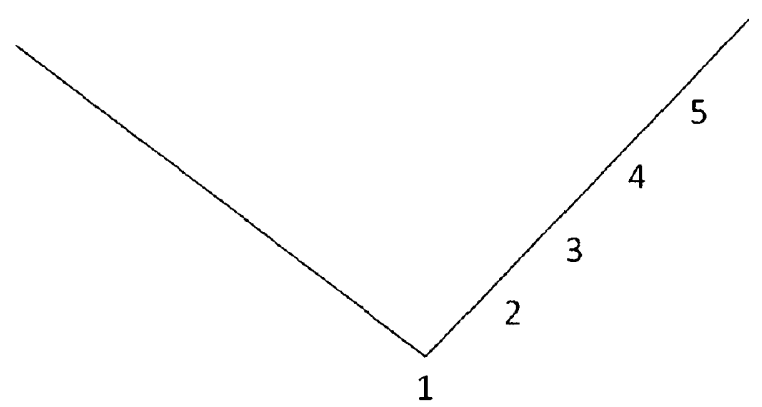

Deep Stations

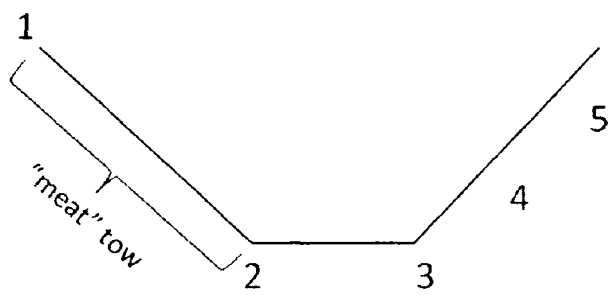

Shallow Stations

Figure 4. Oblique sampling design for deep (max trawl depth between 2700-2900 m) and shallow (max trawl depth $<1700 \mathrm{~m}$ ) stations. The numbers indicate the series of codend openings. 


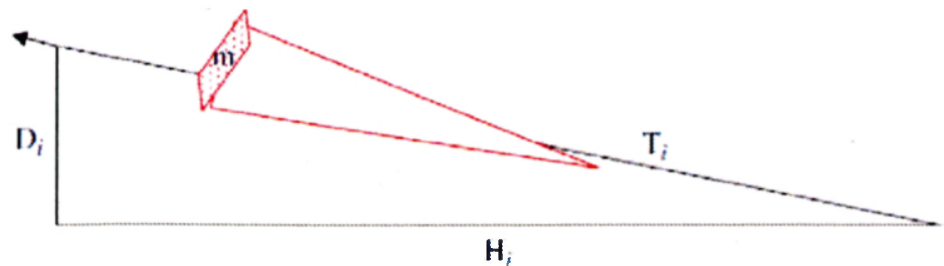

Figure 5. Calculation of volume filtered by the macrozooplankton trawl: $T_{i}=$ towing distance at depth interval $i, m=$ area of the mouth opening of the trawl $\left(36 \mathrm{~m}^{2}\right), D_{i}=$ height of the depth interval $i$, and $\mathrm{H}_{\mathrm{i}}=$ horizontal distance covered while trawling at depth interval $i$ (Wenneck et al. 2008). 

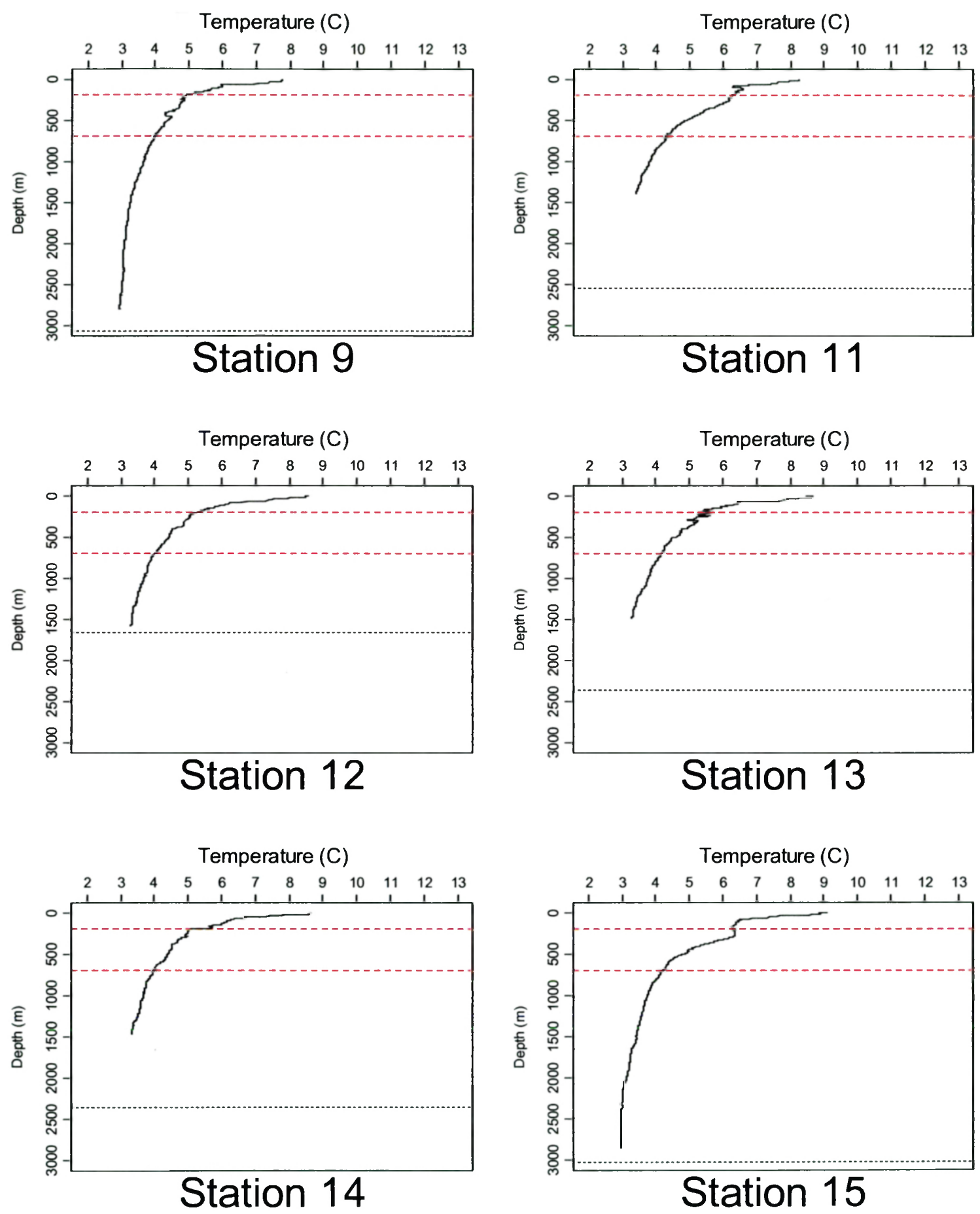

Figure 6. In situ temperature profiles for stations in the study area. Red dashed lines at 200 and $700 \mathrm{~m}$ represent isobaths used to characterize hydrographic regimes by temperature. Black dotted line represents mean bottom depth at station. 

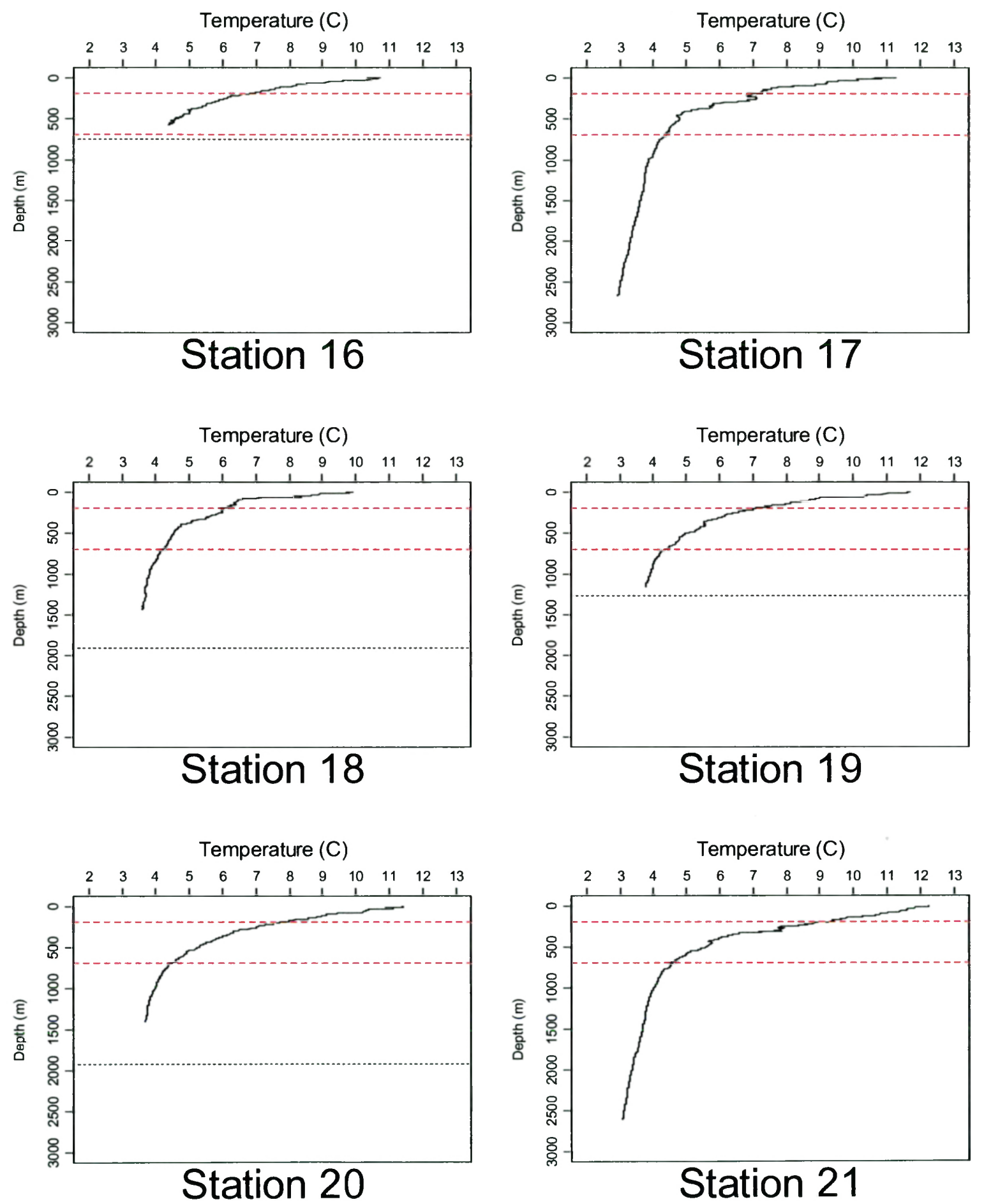

Figure 6 (cont.). In situ temperature profiles for stations in the study area. Red dashed lines at 200 and $700 \mathrm{~m}$ represent isobaths used to characterize hydrographic regimes by temperature. Black dotted line represents mean bottom depth at station. 

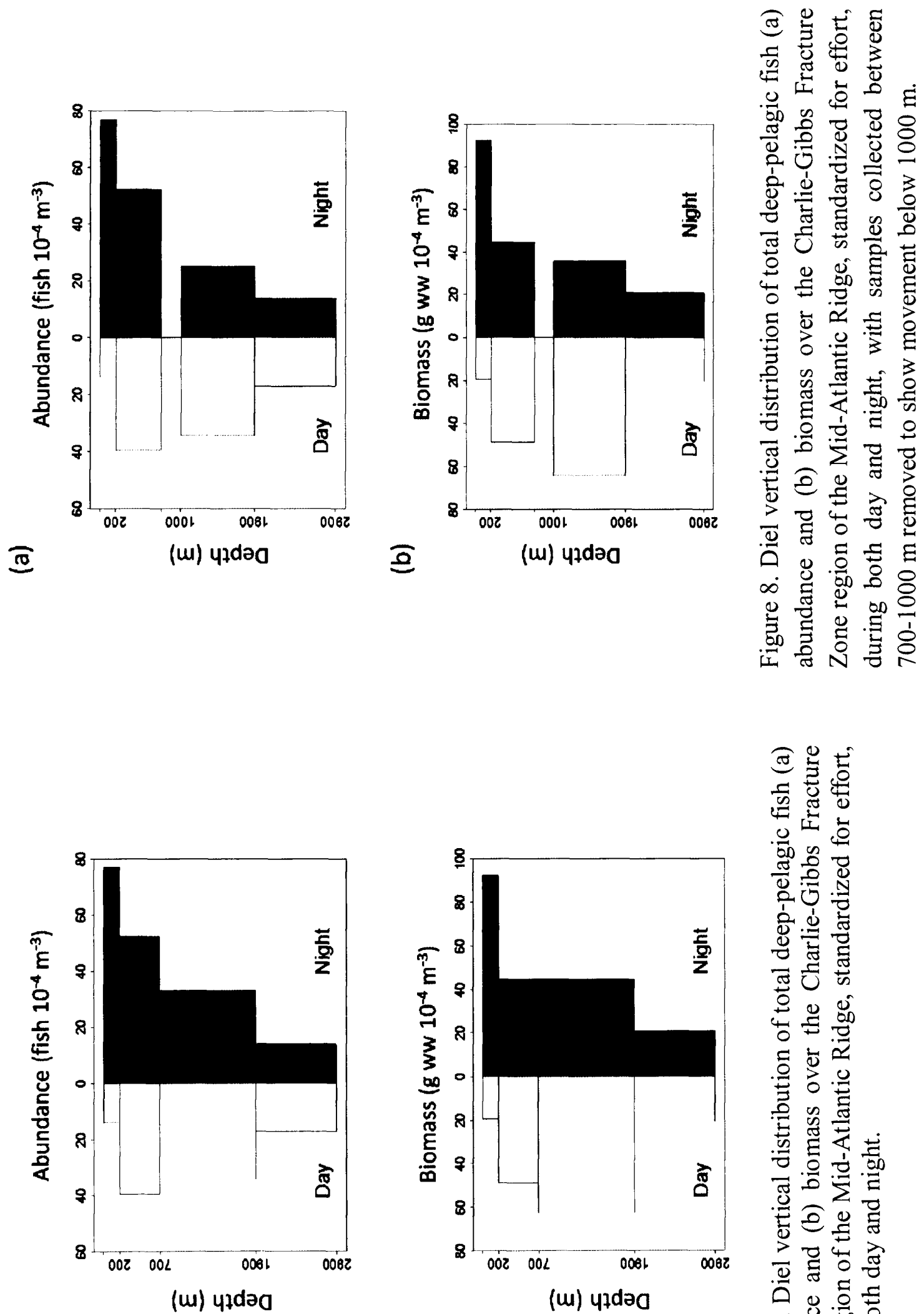

త

(w) y?də0

르

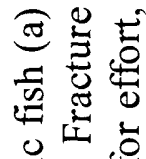
品

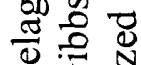
운 의 票 无釈 芒焉

.

을

可

贸

용

氖五

음

응도 둥

윰

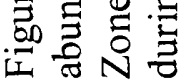




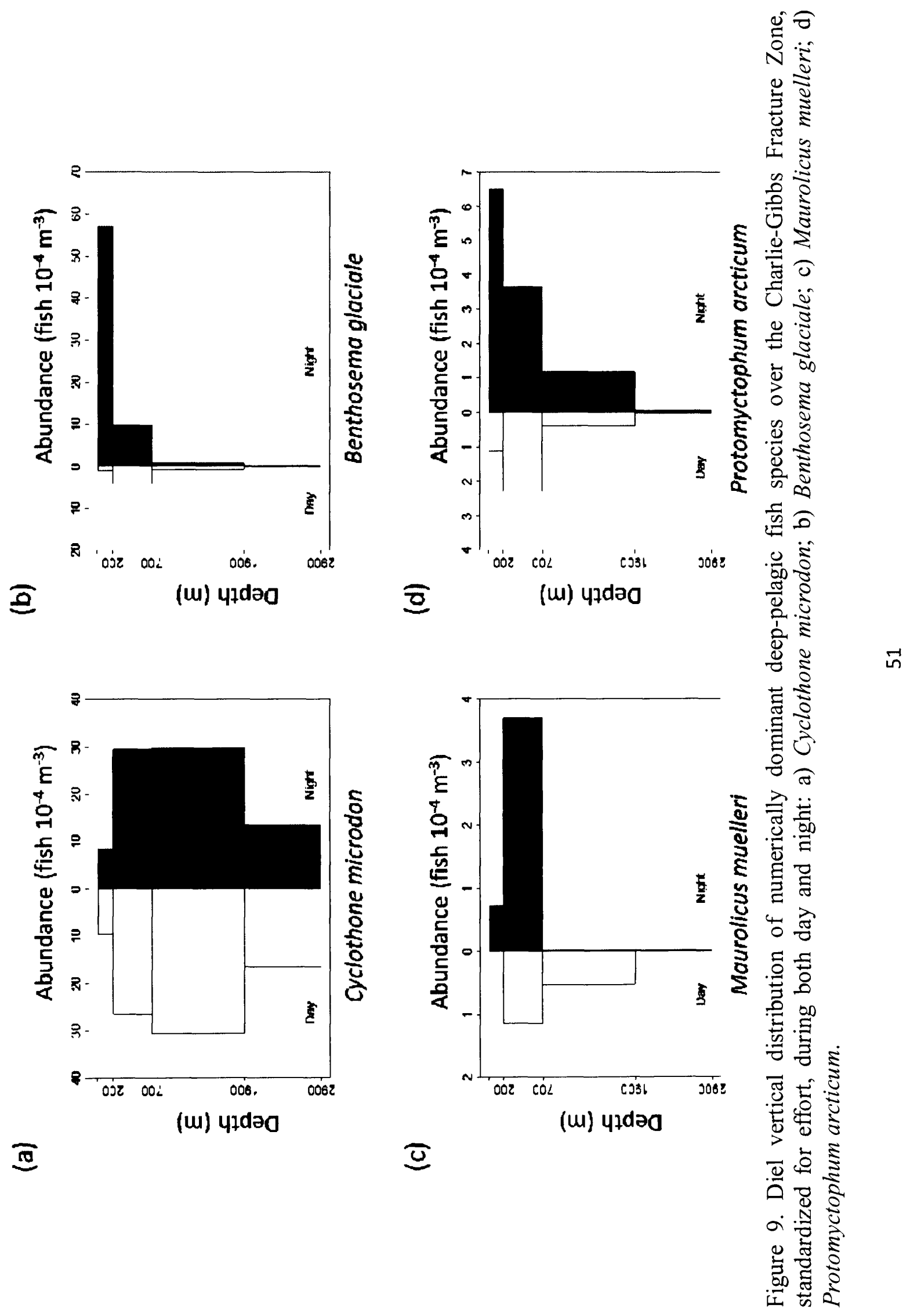



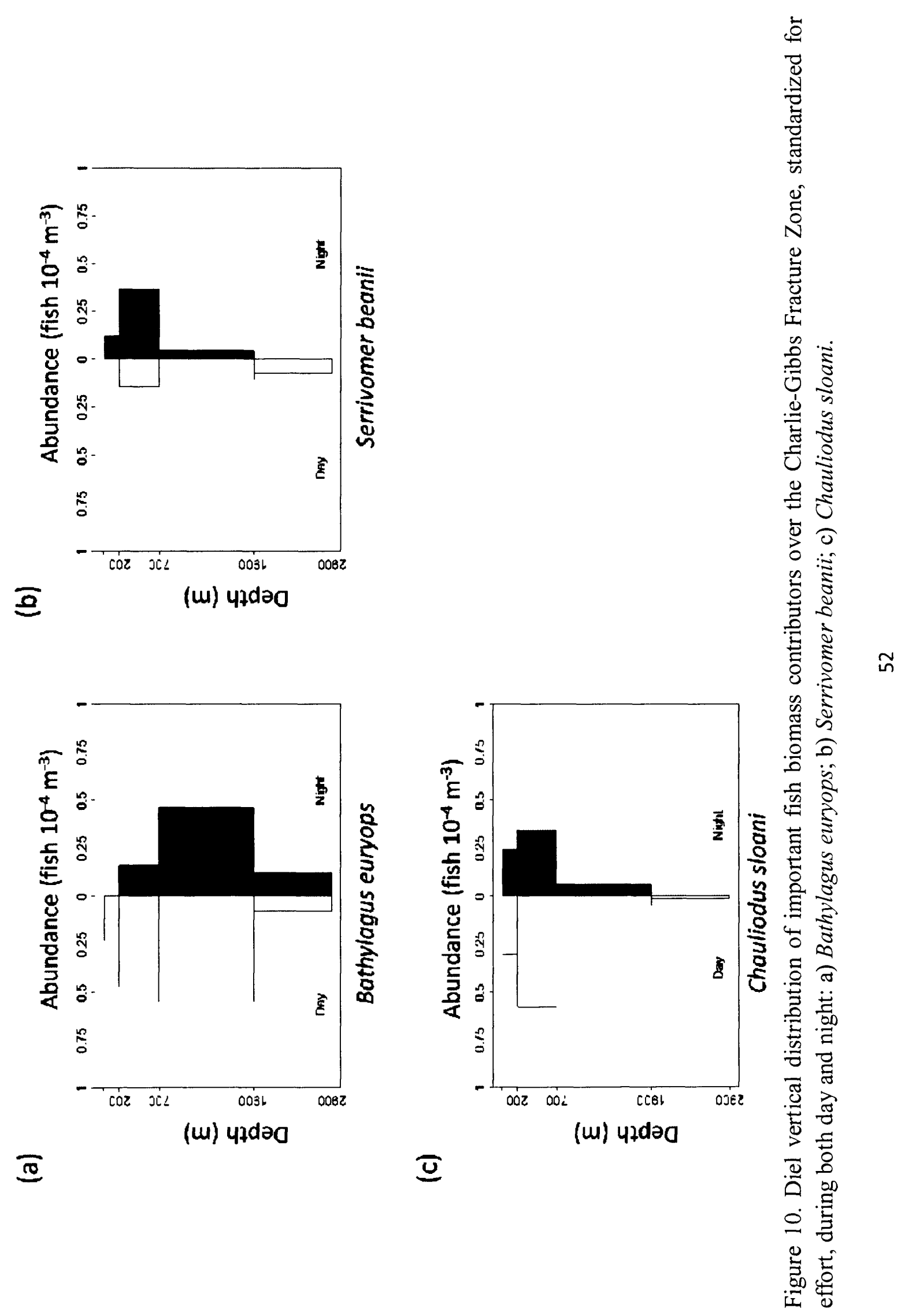


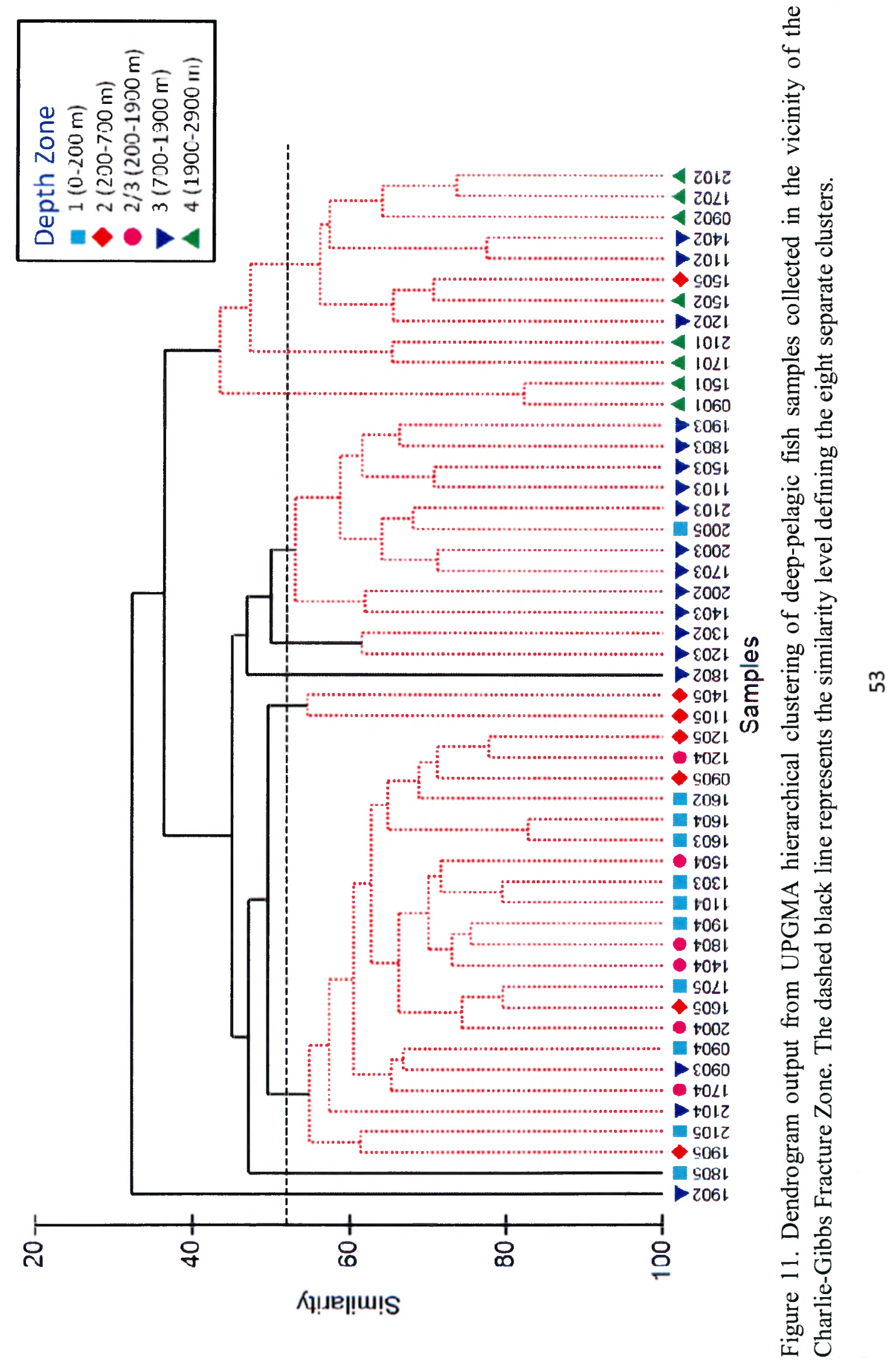


青

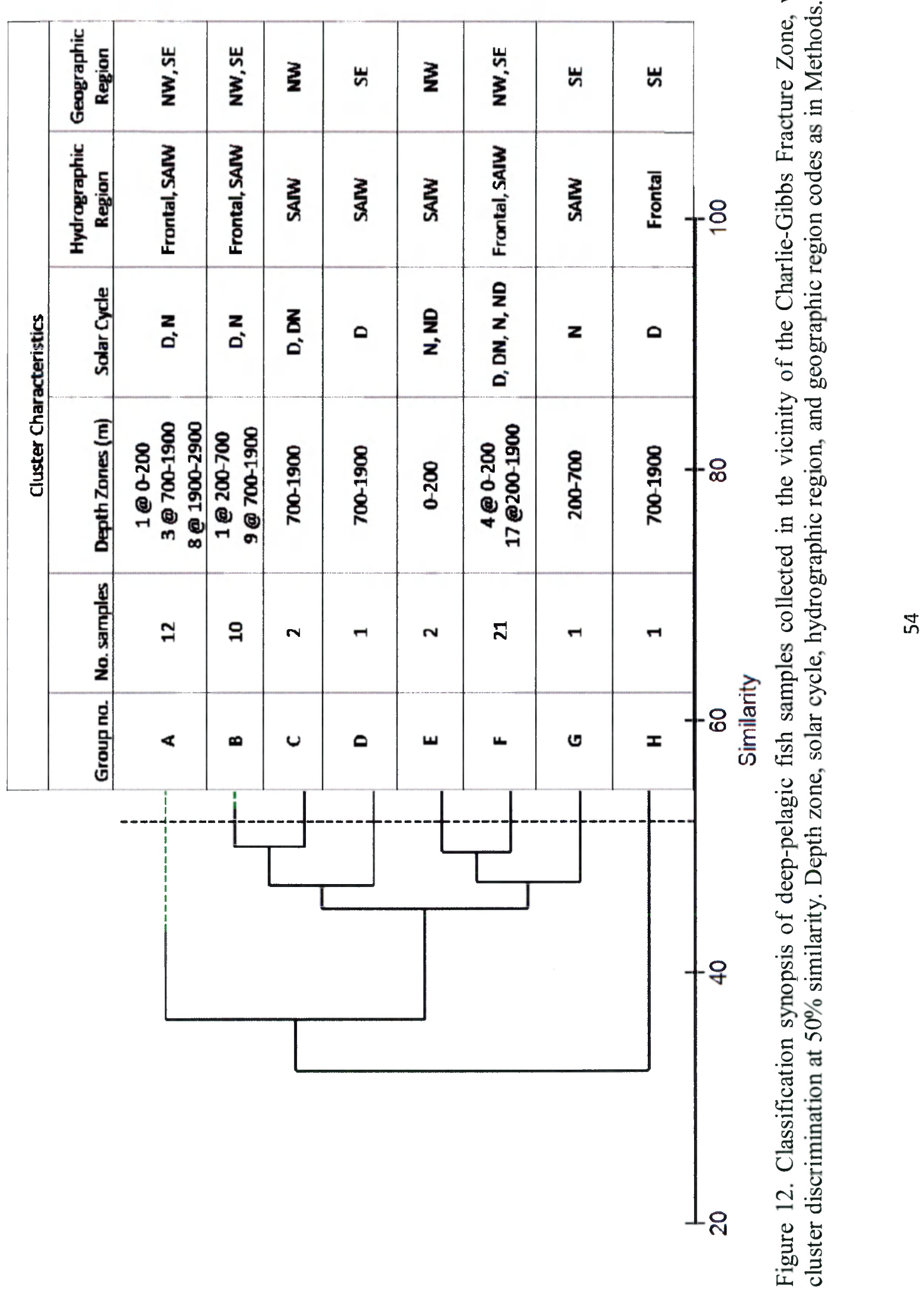




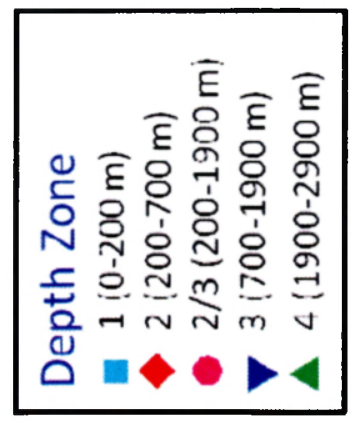

崟 害

ป ข

छั

坖主

올

岤

光管

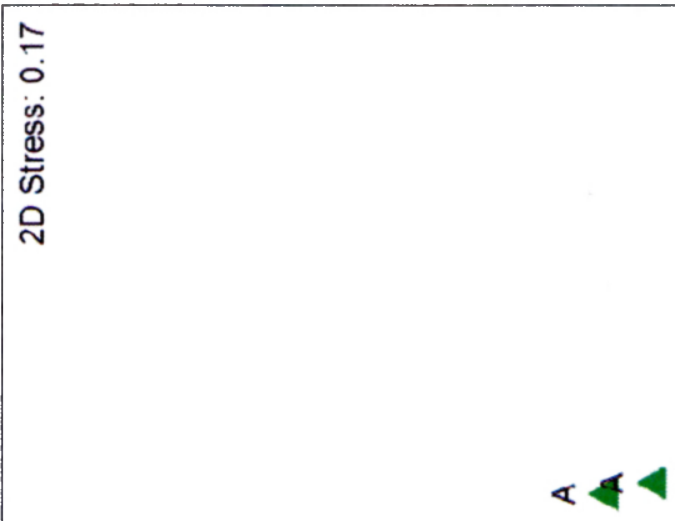

w

$\varangle<$

.릉 ㅇํㅇ

퐆

. 당

공

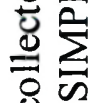

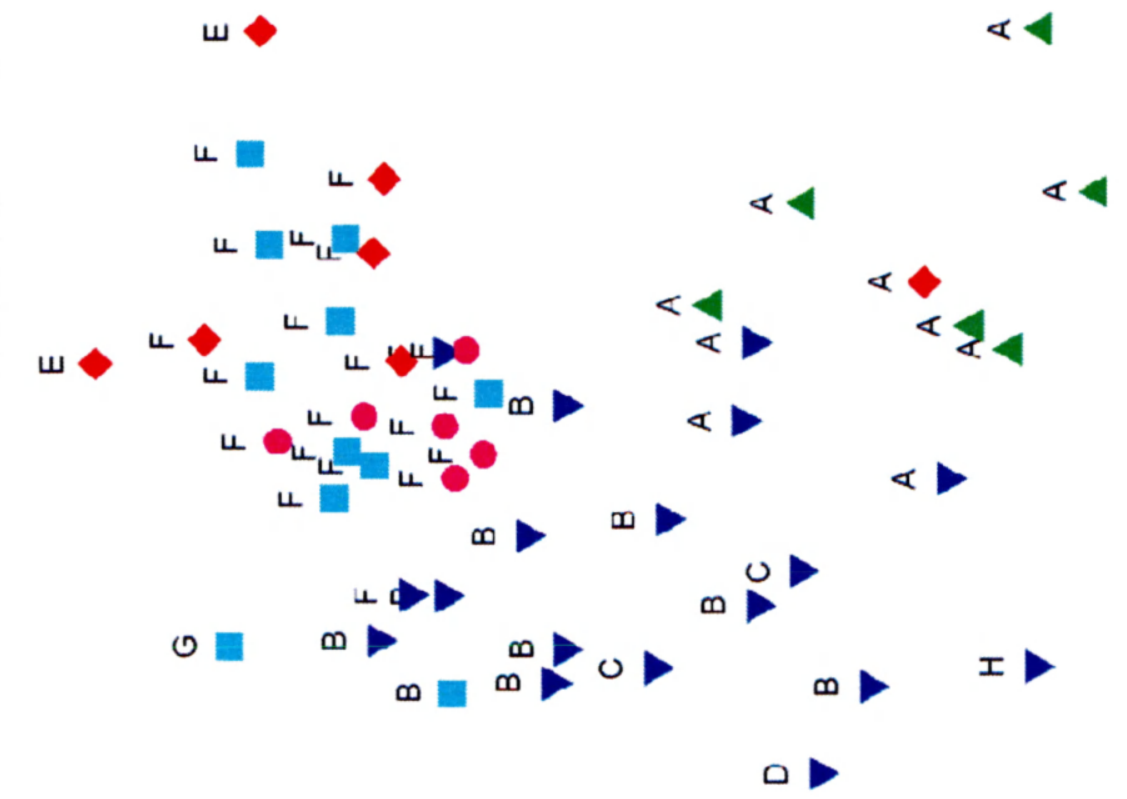




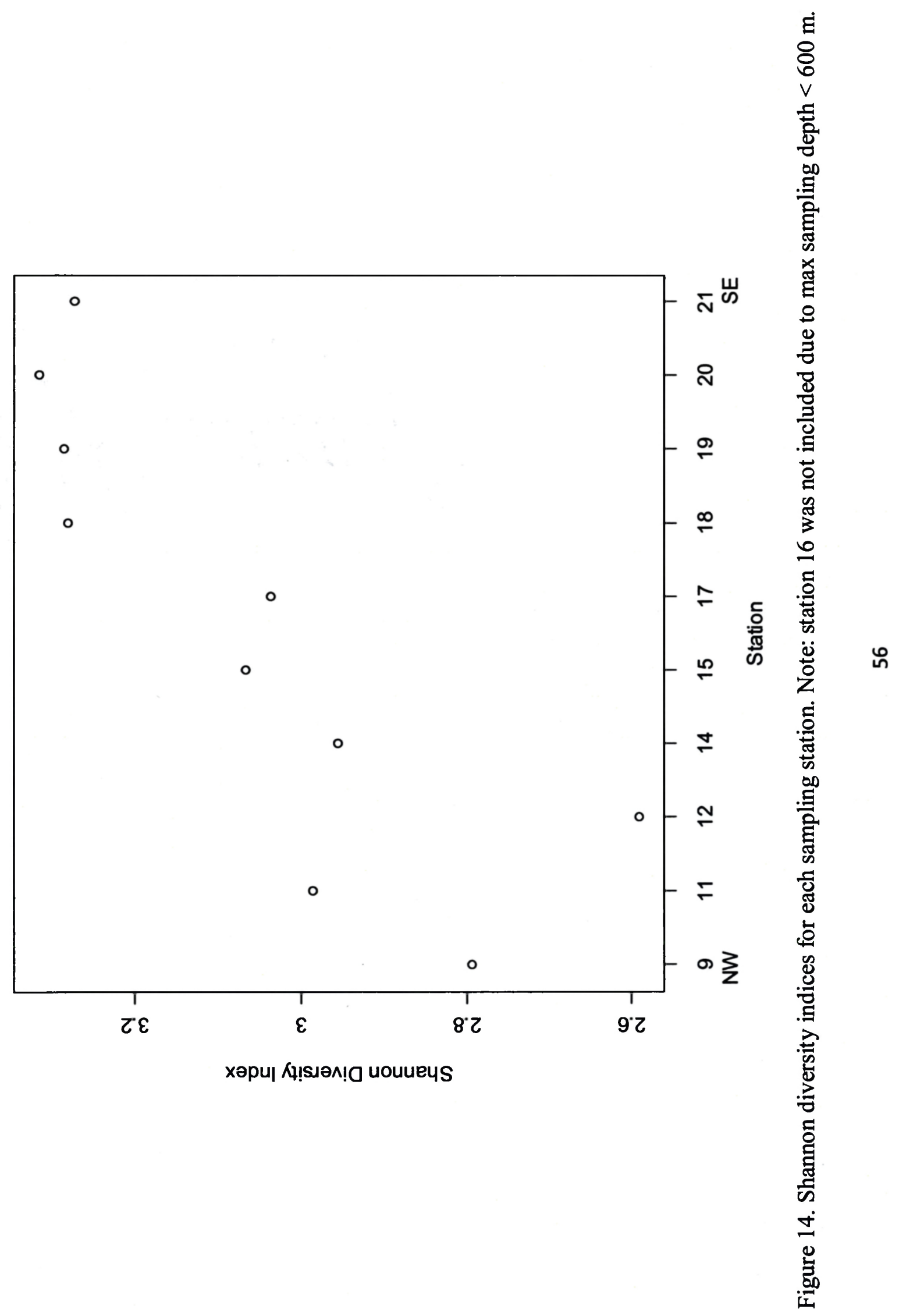



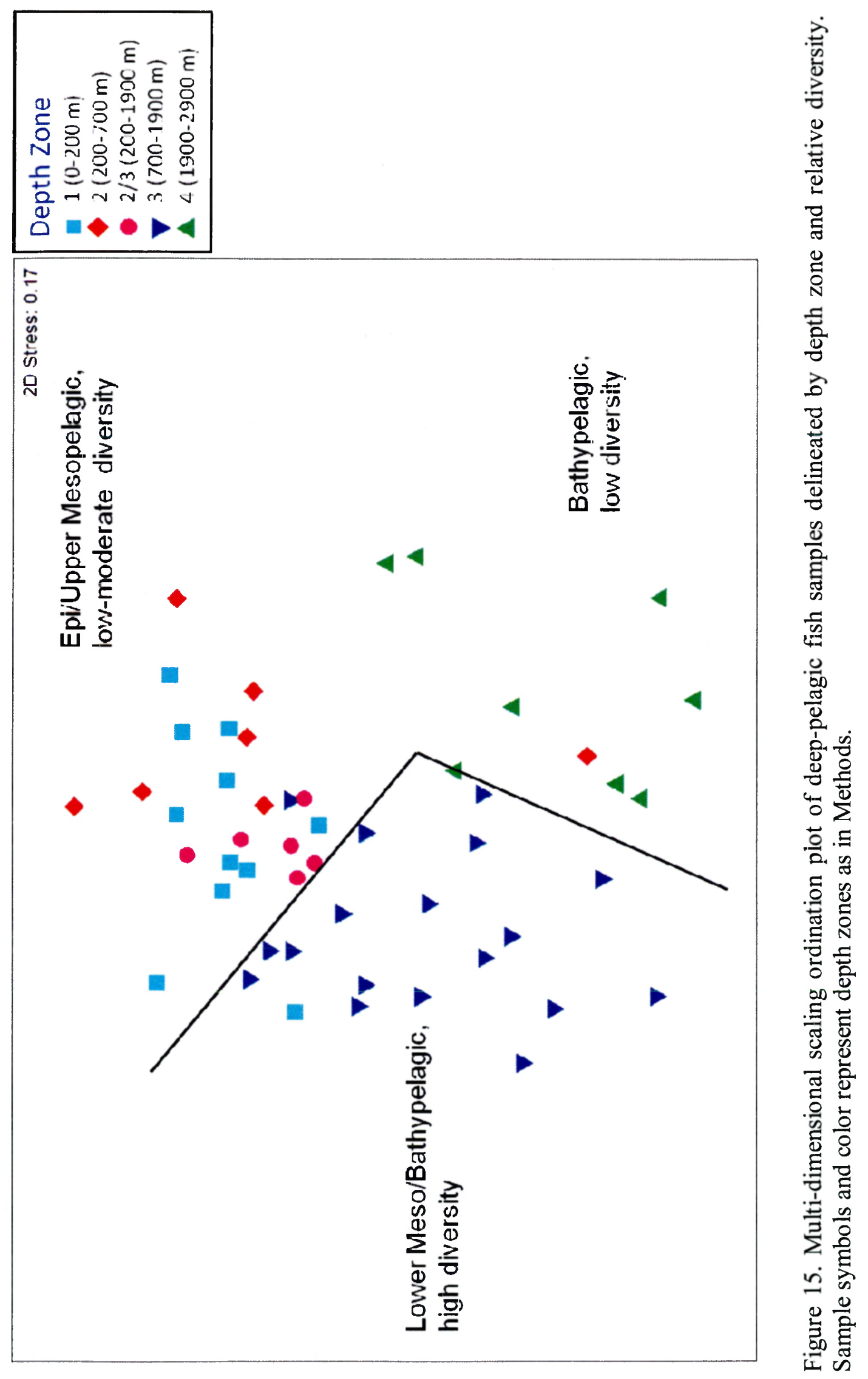

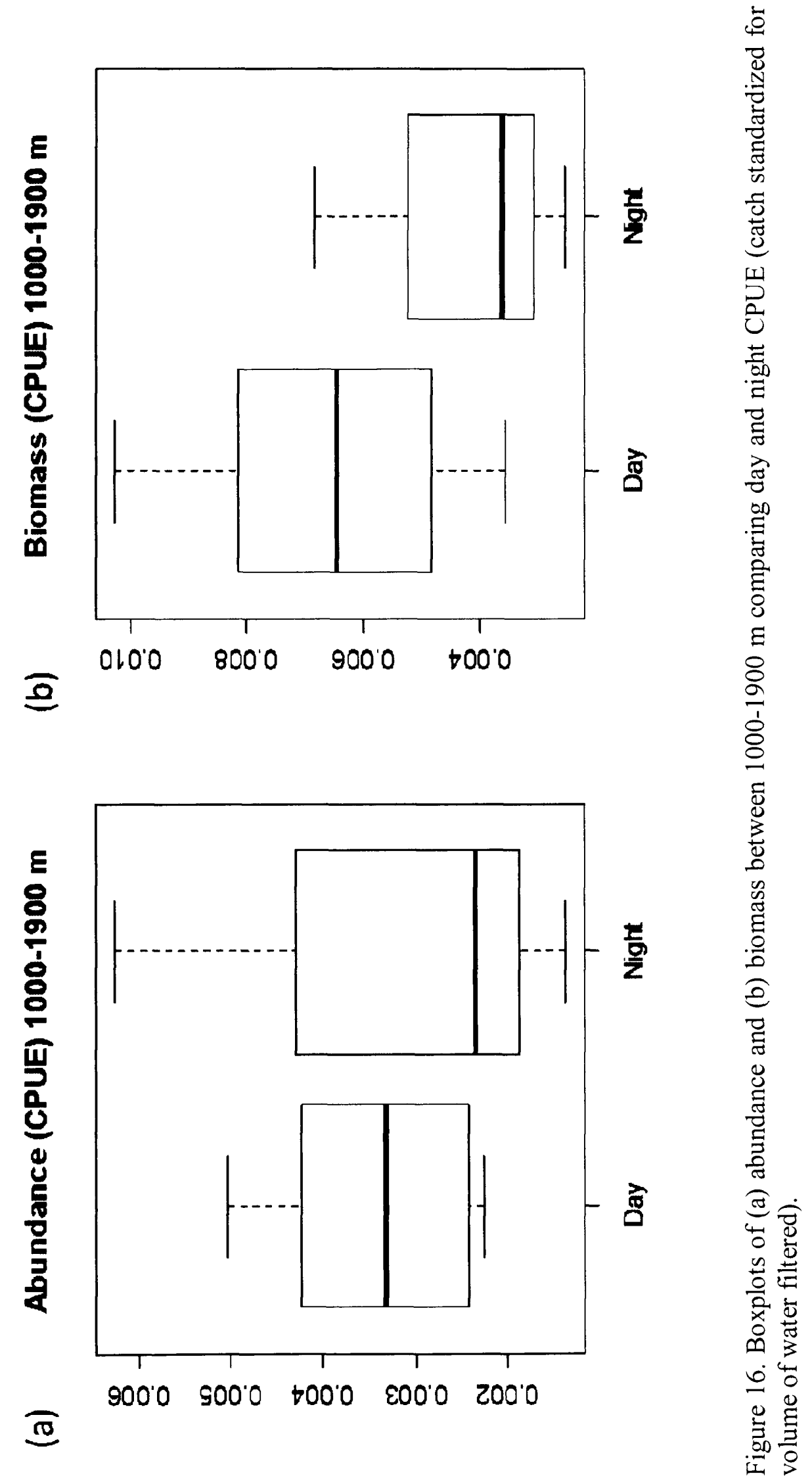
Appendix I. Schematic of the macrozooplankton trawl (after Wenneck et al. 2008), with dimensions, and stretched mesh sizes. The rigging with strapping, trawl doors, bridles, floats, and weights are shown below the net diagrams. Elements not shown are the multisampler with the five $30-\mathrm{m}$ long codends and collection buckets.

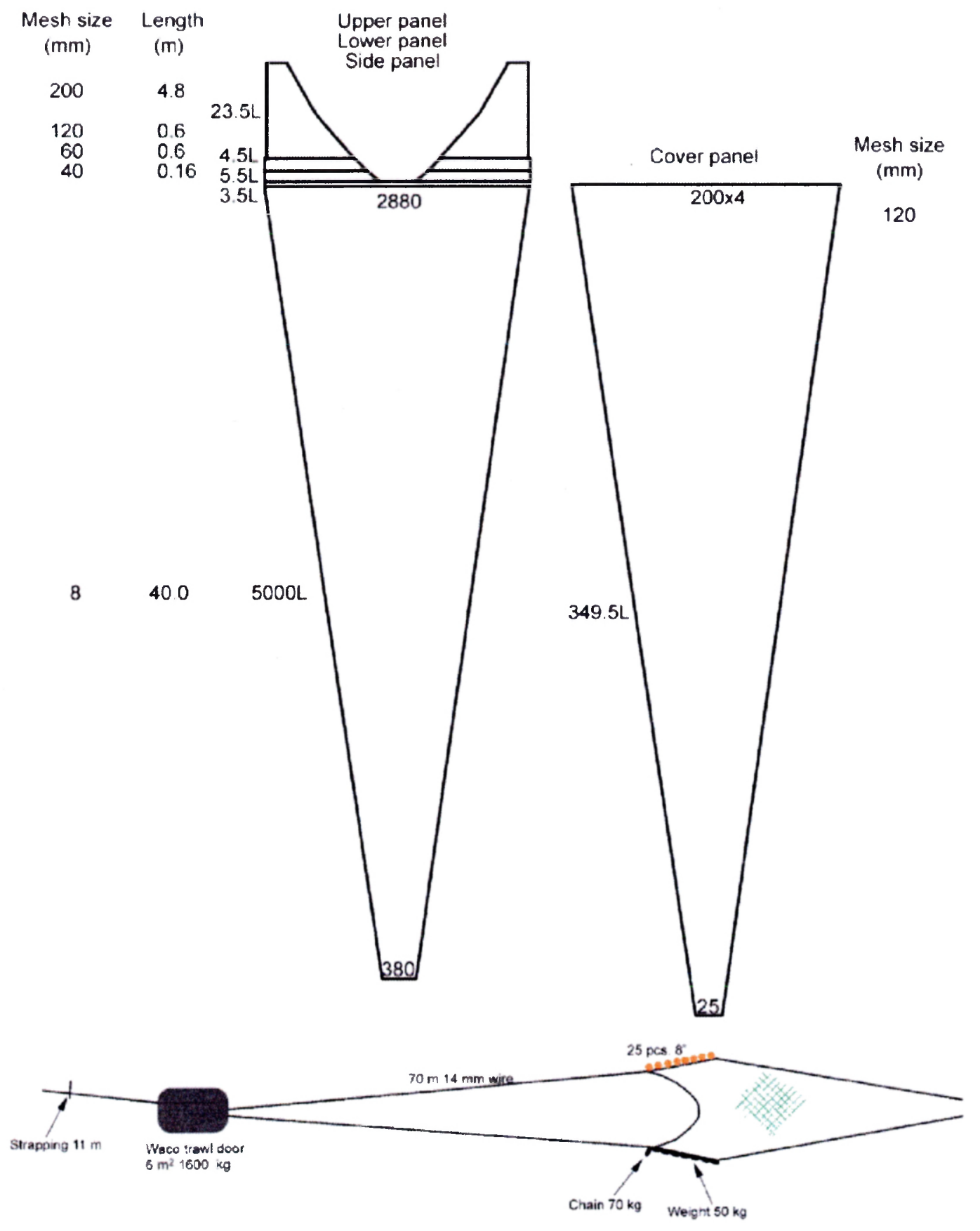


Appendix II. Pelagic fishes collected from 0-2900 m during the 2009 Henry B. Bigelow expedition in the vicinity of the Charlie-Gibbs Fracture Zone of the northern MidAtlantic Ridge, listed in rank abundance.

\begin{tabular}{|c|c|c|c|c|c|c|}
\hline Taxon Name & Family & $\begin{array}{c}\text { Raw } \\
\text { abundance }\end{array}$ & $\begin{array}{c}\% \text { of total } \\
\text { abund }\end{array}$ & $\begin{array}{c}\text { Raw } \\
\text { biomass } \\
\text { (g) }\end{array}$ & $\begin{array}{l}\% \text { of total } \\
\text { biomass }\end{array}$ & $\begin{array}{l}\text { Frequency } \\
\text { of } \\
\text { occurrence }\end{array}$ \\
\hline Cyclothone microdon & Gonostomatidae & 14412 & $78 \%$ & 9087 & $36 \%$ & $100 \%$ \\
\hline Benthosema glaciale & Myctophidae & 1702 & $9 \%$ & 1771 & $7 \%$ & $80 \%$ \\
\hline Protomyctophum arcticum & Myctophidae & 853 & $5 \%$ & 599 & $2 \%$ & $74 \%$ \\
\hline Maurolicus muelleri & Sternoptychidae & 312 & $2 \%$ & 287 & $1 \%$ & $42 \%$ \\
\hline Bathylagus euryops & Bathylagidae & 226 & $1 \%$ & 4089 & $16 \%$ & $74 \%$ \\
\hline Cyclothone braneri & Gonostomatidae & 220 & $1 \%$ & 41 & $<1 \%$ & $50 \%$ \\
\hline Myctophidae (damaged) & Myctophidae & 100 & $1 \%$ & 6 & $<1 \%$ & $6 \%$ \\
\hline Chauliodus sloani & Stomiidae & 72 & $<1 \%$ & 1251 & $5 \%$ & $54 \%$ \\
\hline Scopelogadus m. mizolepis & Melamphaidae & 72 & $<1 \%$ & 1222 & $5 \%$ & $34 \%$ \\
\hline Serrivomer beanii & Serrivomeridae & 54 & $<1 \%$ & 2042 & $8 \%$ & $54 \%$ \\
\hline Stomias boa & Stomiidae & 47 & $<1 \%$ & 637 & $3 \%$ & $50 \%$ \\
\hline Lampanyctus macdonaldi & Myctophidae & 43 & $<1 \%$ & 156 & $1 \%$ & $36 \%$ \\
\hline Poromitra megalops & Melamphaidae & 41 & $<1 \%$ & 76 & $<1 \%$ & $36 \%$ \\
\hline Scopeloberyx opisthopterus & Melamphaidae & 36 & $<1 \%$ & 38 & $<1 \%$ & $24 \%$ \\
\hline Myctophum punctatum & Myctophidae & 34 & $<1 \%$ & 188 & $1 \%$ & $26 \%$ \\
\hline Poromitra crassiceps & Melamphaidae & 28 & $<1 \%$ & 390 & $2 \%$ & $24 \%$ \\
\hline Scopeloberyx robustus & Melamphaidae & 28 & $<1 \%$ & 91 & $<1 \%$ & $18 \%$ \\
\hline Gonostoma bathyphilum & Gonostomatidae & 15 & $<1 \%$ & 237 & $1 \%$ & $16 \%$ \\
\hline Scopelogadus beanii & Melamphaidae & 15 & $<1 \%$ & 196 & $1 \%$ & $8 \%$ \\
\hline Cyclothone pallida & Gonostomatidae & 15 & $<1 \%$ & 30 & $<1 \%$ & $8 \%$ \\
\hline Eurypharynx pelecanoides & Eurypharyngidae & 12 & $<1 \%$ & 488 & $2 \%$ & $20 \%$ \\
\hline Malacosteus niger & Stomiidae & 12 & $<1 \%$ & 448 & $2 \%$ & $16 \%$ \\
\hline Vinciguerria attenuata & Phosichthyidae & 11 & $<1 \%$ & 54 & $<1 \%$ & $8 \%$ \\
\hline Argvropelecus hemigvmnus & Sternoptychidae & 10 & $<1 \%$ & 14 & $<1 \%$ & $16 \%$ \\
\hline Borostomias anatrcticus & Stomiidae & 9 & $<1 \%$ & 765 & $3 \%$ & $16 \%$ \\
\hline Notoscopelus bolini & Myctophidae & 9 & $<1 \%$ & 49 & $<1 \%$ & $14 \%$ \\
\hline Melamphaes spp. (unident.) & Melamphaidae & 9 & $<1 \%$ & 44 & $<1 \%$ & $14 \%$ \\
\hline Platytroctidae & Platytroctidae & 9 & $<1 \%$ & 8 & $<1 \%$ & $12 \%$ \\
\hline Taaningichthys bathyphilus & Myctophidae & 7 & $<1 \%$ & 16 & $<1 \%$ & $12 \%$ \\
\hline Notoscopelus sp. (damaged) & Myctophidae & 6 & $<1 \%$ & 23 & $<1 \%$ & $4 \%$ \\
\hline Sternoptvx diaphana & Sternoptychidae & 6 & $<1 \%$ & 8 & $<1 \%$ & $10 \%$ \\
\hline Nannobrachium achirus & Myctophidae & 5 & $<1 \%$ & 16 & $<1 \%$ & $8 \%$ \\
\hline Psdenos spp. (unident.) & Liparidae & 5 & $<1 \%$ & 7 & $<1 \%$ & $8 \%$ \\
\hline Parabrotula plagiophthalma & Parabrotulidae & 4 & $<1 \%$ & 4 & $<1 \%$ & $8 \%$ \\
\hline Symbolophorus veranyi & Myctophidae & 4 & $<1 \%$ & 2 & $<1 \%$ & $6 \%$ \\
\hline
\end{tabular}




\begin{tabular}{|c|c|c|c|c|c|c|}
\hline Taxon Name & Family & $\begin{array}{c}\text { Raw } \\
\text { abundance }\end{array}$ & $\begin{array}{l}\% \text { of total } \\
\text { abund }\end{array}$ & $\begin{array}{c}\text { Raw } \\
\text { biomass } \\
\text { (g) }\end{array}$ & $\begin{array}{l}\% \text { of total } \\
\text { biomass }\end{array}$ & $\begin{array}{c}\text { Frequency } \\
\text { of } \\
\text { occurrence }\end{array}$ \\
\hline Maulisia microlepis & Platytroctidae & 3 & $<1 \%$ & 92 & $<1 \%$ & $6 \%$ \\
\hline Lophodolos acanthognathus & Oneirodidae & 3 & $<1 \%$ & 31 & $<1 \%$ & $2 \%$ \\
\hline Saccopharynx ampullaceus & Saccopharyngidae & 2 & $<1 \%$ & 211 & $1 \%$ & $4 \%$ \\
\hline Melanolagus bericoides & Bathylagidae & 2 & $<1 \%$ & 42 & $<1 \%$ & $2 \%$ \\
\hline Gadiformes (juvenile) & & 2 & $<1 \%$ & 16 & $<1 \%$ & $4 \%$ \\
\hline Alepisaurus brevirostris & Alepisauridae & 2 & $<1 \%$ & 7 & $<1 \%$ & $4 \%$ \\
\hline Normichthys operosus & Platytroctidae & 2 & $<1 \%$ & 6 & $<1 \%$ & $4 \%$ \\
\hline Coryphaenoides sp. (juvenile) & Macrouridae & 2 & $<1 \%$ & 4 & $<1 \%$ & $4 \%$ \\
\hline Leptostomias sp. (damaged) & Stomiidae & 2 & $<1 \%$ & 4 & $<1 \%$ & $2 \%$ \\
\hline Nannobrachium sp. (damaged) & Myctophidae & 2 & $<1 \%$ & 2 & $<1 \%$ & $2 \%$ \\
\hline Lampanyctus photonotus & Myctophidae & 2 & $<1 \%$ & 1 & $<1 \%$ & $2 \%$ \\
\hline Melanocetus murrayi & Melanocetidae & 1 & $<1 \%$ & 206 & $1 \%$ & $2 \%$ \\
\hline Anoplogaster cornuta & Anoplogasteridae & 1 & $<1 \%$ & 139 & $1 \%$ & $2 \%$ \\
\hline Caristiidae (unident.) & Caristiidae & 1 & $<1 \%$ & 105 & $<1 \%$ & $2 \%$ \\
\hline Sigmops elongatum & Gonostomatidae & 1 & $<1 \%$ & 48 & $<1 \%$ & $2 \%$ \\
\hline Linophrynidae (unident.) & Linophrynidae & 1 & $<1 \%$ & 45 & $<1 \%$ & $2 \%$ \\
\hline Derichthys serpentinus & Derichthyidae & 1 & $<1 \%$ & 22 & $<1 \%$ & $2 \%$ \\
\hline Lampadena speculiguera & Myctophidae & 1 & $<1 \%$ & 20 & $<1 \%$ & $2 \%$ \\
\hline Melamphaes polylepis & Melamphaidae & 1 & $<1 \%$ & 20 & $<1 \%$ & $2 \%$ \\
\hline Argyropelecus gigas & Sternoptychidae & 1 & $<1 \%$ & 11 & $<1 \%$ & $2 \%$ \\
\hline Xenodermichthys copei & Alepocephalidae & 1 & $<1 \%$ & 9 & $<1 \%$ & $2 \%$ \\
\hline Chiasmodon niger & Chiasmodontidae & 1 & $<1 \%$ & 6 & $<1 \%$ & $2 \%$ \\
\hline Oneirodes eschrichtii & Oneirodidae & 1 & $<1 \%$ & 6 & $<1 \%$ & $2 \%$ \\
\hline Sternoptyx pseudobscura & Sternoptychidae & 1 & $<1 \%$ & 6 & $<1 \%$ & $2 \%$ \\
\hline Alepocephalus sp. (unident.) & Alepocephalidae & 1 & $<1 \%$ & 4 & $<1 \%$ & $2 \%$ \\
\hline Bathytroctes microlepis & Alepocephalidae & 1 & $<1 \%$ & 4 & $<1 \%$ & $2 \%$ \\
\hline Melanostigma atlanticum & Zoarcidae & 1 & $<1 \%$ & 4 & $<1 \%$ & $2 \%$ \\
\hline Gaidropsarus argentatus & Lotidae & 1 & $<1 \%$ & 3 & $<1 \%$ & $2 \%$ \\
\hline Bajacalifornia megalops & Alepocephalidae & 1 & $<1 \%$ & 2 & $<1 \%$ & $2 \%$ \\
\hline Dolopichthys sp. (unident) & Oneirodidae & 1 & $<1 \%$ & 2 & $<1 \%$ & $2 \%$ \\
\hline Holtbyrnia anomala & Platytroctidae & 1 & $<1 \%$ & 2 & $<1 \%$ & $2 \%$ \\
\hline Paralepididae (unident.) & Paralepididae & 1 & $<1 \%$ & 2 & $<1 \%$ & $2 \%$ \\
\hline Bathylagichthys grevae & Bathylagidae & 1 & $<1 \%$ & 1 & $<1 \%$ & $2 \%$ \\
\hline Howella brodei & Howellidae & 1 & $<1 \%$ & 1 & $<1 \%$ & $2 \%$ \\
\hline Lampanyctus pusillus & Myctophidae & 1 & $<1 \%$ & 1 & $<1 \%$ & $2 \%$ \\
\hline Melanonus zugmaveri & Melanonidae & 1 & $<1 \%$ & 1 & $<1 \%$ & $2 \%$ \\
\hline Notolychnus valdiviae & Myctophidae & 1 & $<1 \%$ & 1 & $<1 \%$ & $2 \%$ \\
\hline Trachipterus arcticus* & Trachipteridae & 1 & $<1 \%$ & 1 & $<1 \%$ & $2 \%$ \\
\hline Valenciennellus tripunctulatus & Sternoptychidae & 1 & $<1 \%$ & 1 & $<1 \%$ & $2 \%$ \\
\hline Zoarcidae (unident.) & Zoarcidae & 1 & $<1 \%$ & 1 & $<1 \%$ & $2 \%$ \\
\hline
\end{tabular}


Appendix III. Indices of diversity by sample for each station. $S=$ species richness, $H^{\prime}=$ Shannon diversity index. Depth zone and solar cycle codes as in Methods.

\begin{tabular}{lccccc}
\hline Sample & Station & $\boldsymbol{S}$ & $\boldsymbol{H}^{\prime}$ & Zone & $\begin{array}{c}\text { Solar } \\
\text { Cycle }\end{array}$ \\
\hline 0901 & 9 & 4 & 1.37 & 4 & $\mathrm{~N}$ \\
0902 & 9 & 5 & 1.50 & 4 & $\mathrm{~N}$ \\
0903 & 9 & 13 & 2.43 & 3 & $\mathrm{~N}$ \\
0904 & 9 & 10 & 2.16 & 2 & $\mathrm{ND}$ \\
0905 & 9 & 9 & 2.10 & 1 & $\mathrm{ND}$ \\
1102 & 11 & 6 & 1.60 & 3 & $\mathrm{~N}$ \\
1103 & 11 & 13 & 2.37 & 3 & $\mathrm{~N}$ \\
1104 & 11 & 15 & 2.59 & 2 & $\mathrm{~N}$ \\
1105 & 11 & 11 & 2.24 & 1 & $\mathrm{~N}$ \\
1202 & 12 & 5 & 1.41 & 3 & $\mathrm{D}$ \\
1203 & 12 & 12 & 2.31 & 3 & $\mathrm{D}$ \\
1204 & 12 & 8 & 1.96 & $2 / 3$ & $\mathrm{D}$ \\
1205 & 12 & 7 & 1.88 & 1 & $\mathrm{D}$ \\
1402 & 14 & 9 & 1.98 & 3 & $\mathrm{~N}$ \\
1403 & 14 & 13 & 2.40 & 3 & $\mathrm{~N}$ \\
1404 & 14 & 13 & 2.46 & $2 / 3$ & $\mathrm{ND}$ \\
1405 & 14 & 4 & 1.30 & 1 & $\mathrm{ND}$ \\
1501 & 15 & 5 & 1.54 & 4 & $\mathrm{D}$ \\
1502 & 15 & 4 & 1.21 & 4 & $\mathrm{D}$ \\
1503 & 15 & 17 & 2.68 & 3 & $\mathrm{D}$ \\
1504 & 15 & 11 & 2.30 & $2 / 3$ & $\mathrm{D}$ \\
1505 & 15 & 3 & 1.01 & 1 & $\mathrm{D}$ \\
1602 & 16 & 12 & 2.33 & 2 & $\mathrm{~N}$ \\
1603 & 16 & 6 & 1.76 & 2 & $\mathrm{~N}$ \\
1604 & 16 & 5 & 1.58 & 2 & $\mathrm{~N}$ \\
1605 & 16 & 9 & 2.14 & 1 & $\mathrm{~N}$ \\
1701 & 17 & 3 & 1.04 & 4 & $\mathrm{D}$ \\
1702 & 17 & 7 & 1.72 & 4 & $\mathrm{D}$ \\
1703 & 17 & 12 & 2.34 & 3 & $\mathrm{D}$ \\
1704 & 17 & 16 & 2.67 & $2 / 3$ & $\mathrm{D}$ \\
1705 & 17 & 9 & 2.12 & 2 & $\mathrm{D}$ \\
1802 & 18 & 15 & 2.57 & 3 & $\mathrm{D}$ \\
1803 & 18 & 21 & 2.93 & 3 & $\mathrm{~N}$ \\
1804 & 18 & 13 & 2.48 & $2 / 3$ & $\mathrm{~N}$ \\
1805 & 18 & 9 & 2.04 & 2 & $\mathrm{~N}$ \\
1902 & 19 & 11 & 2.27 & 3 & $\mathrm{D}$ \\
1903 & 19 & 23 & 3.04 & 3 & $\mathrm{D}$ \\
& & & & &
\end{tabular}




\begin{tabular}{lccccc}
\hline Sample & Station & S & $\mathbf{H}^{\prime}$ & Zone & $\begin{array}{c}\text { Solar } \\
\text { Cycle }\end{array}$ \\
\hline 1904 & 19 & 16 & 2.70 & 2 & $\mathrm{D}$ \\
1905 & 19 & 6 & 1.76 & 1 & $\mathrm{D}$ \\
2002 & 20 & 11 & 2.20 & 3 & $\mathrm{D}$ \\
2003 & 20 & 18 & 2.78 & 3 & $\mathrm{D}$ \\
2004 & 20 & 14 & 2.53 & $2 / 3$ & $\mathrm{D}$ \\
2005 & 20 & 18 & 2.76 & 2 & $\mathrm{D}$ \\
2101 & 21 & 4 & 1.32 & 4 & $\mathrm{~N}$ \\
2102 & 21 & 5 & 1.35 & 4 & $\mathrm{~N}$ \\
2103 & 21 & 21 & 2.91 & 3 & $\mathrm{D}$ \\
2104 & 21 & 19 & 2.87 & 3 & $\mathrm{D}$ \\
2105 & 21 & 9 & 2.14 & 2 & $\mathrm{D}$ \\
\hline
\end{tabular}




\section{VITA}

\section{APRIL BETH COOK}

Born in Johnstown, Ohio, 12 April 1978. Graduated with honor from Lancaster High School in 1996. Earned a B.S. in Marine Science, cum laude from Coastal Carolina University in 2000. Entered the Master of Science program at the Virginia Institute of Marine Science, College of William \& Mary, School of Marine Science in 2009. 